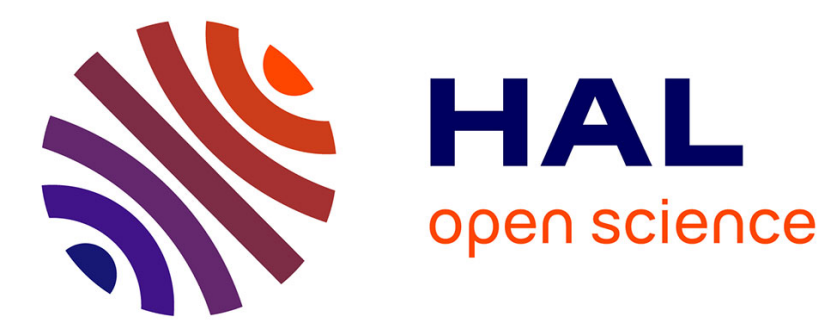

\title{
Confraternal religion: from liberation theology to political reversal
}

\author{
Albert Doja
}

\section{To cite this version:}

Albert Doja. Confraternal religion: from liberation theology to political reversal. History and Anthropology, 2003, 14 (4), pp.349-381. 10.1080/0275720032000156488 . halshs-00405977

\section{HAL Id: halshs-00405977 https://shs.hal.science/halshs-00405977}

Submitted on 13 Oct 2009

HAL is a multi-disciplinary open access archive for the deposit and dissemination of scientific research documents, whether they are published or not. The documents may come from teaching and research institutions in France or abroad, or from public or private research centers.
L'archive ouverte pluridisciplinaire HAL, est destinée au dépôt et à la diffusion de documents scientifiques de niveau recherche, publiés ou non, émanant des établissements d'enseignement et de recherche français ou étrangers, des laboratoires publics ou privés. 


\title{
CONFRATERNAL RELIGION: FROM LIBERATION THEOLOGY TO POLITICAL REVERSAL
}

\author{
ALBERT DOJA \\ University of Limerick
}

\begin{abstract}
Heterodox mystics and heretics of any kind can be sometimes dangerous and other times reliable depending upon political situations, as was the case with Bektashis in Ottoman Anatolia or in early independent Albania. The historical anthropology perspective taken in this article appears helpful in revealing that Bektashism is probably the mystical order of Islam that best exemplifies a transformational pattern from a theological and ideological, as well as cultural, social and political, point of view. The system of beliefs and practices related to Bektashism seems to correspond to a kind of liberation theology, whereas the structure of Bektashi groups corresponds more or less to the type of religious organization conventionally known as "charismatic groups". It becomes understandable, therefore, that their spiritual tendency can meet social, cultural and national perspectives. In turn, when the members of the previously persecuted religious minority have already acquired a degree of religious and political respectability within society at large, the doctrines of heterodoxy and liberation theology fade into the background. In the end, the heirs of the heterodox promoters of spiritual reform and social movement turn into followers and faithful defenders of a legitimate authority. They become the spokespeople for an institutionalized orthodoxy whose support will be sought by the political regime.
\end{abstract}

Keywords: Heterodoxy; Mysticism; Sufism; Bektashi; Albanian

\section{INTRODUCTION}

Ethnographic studies of religion, stuck somewhere between ethnocentrism and literalism, especially in the case of Islam, have brought little distinctive anthropological analysis to bear successfully on the practical realities and political ideologies of religions. In addition, over the last one hundred years, the modern views of the nation-state and all its institutionalized mythologies have confused, erased, desecrated and demolished our understanding of the local definitions and categories of group identity articulated in everyday life.

Heterodox religious movements and the institution of new forms of religion, as in the case of mystical orders of Islam, are decisive for understanding the history of religions in the Southeast European area, which in turn could bring forth insights for understanding the current situation in which group identities are being negotiated and redefined. While mystics do not partake of or express class struggle, their heterodoxy, over and beyond the intensity and power of their beliefs or the radical character of their opposition to the established religion, has always and still necessarily does crystallise political, social and cultural discontent, which is in turn very often ethnicized along nationalist lines.

Correspondence to: Albert Doja, Senior Research Fellow, College of Humanities, University of Limerick, Ireland E-mail: albert.doja@ul.ie 
Although only a minority of Muslims were affiliated with brotherhoods in the world of Islam, these nonetheless have played a major historical role (Trimingham 1971: 218-244). Muslim orders often provided successful missionaries, who converted conquered peoples and developed a popular mysticism conducive to adoption by the masses. Their fervour and spirit, quite different from that of legalist Islam, a spirit that also expressed itself in practical social aspects such as hospitality to travellers and care for the sick and the poor, rendered the mystics the best mediators of Islam to the Christians. In addition, they were often spurred by resistance against the Christian invaders, and victoriously re-conquered several positions. In Muslim empires, they have contributed to the maintenance of local particularisms that are still observed today. Perhaps one of the best-known cases in anthropological literature is Evans-Pritchard's (1949) account of the Senussi of Cyrenaica, who were able to coordinate the Order's lodges to the Bedouin tribal structure while maintaining the organization intact and keeping control of it. Having risen up in opposition to Italian colonial domination, the Senussi succeeded in achieving the evolution of their Order into the Kingdom of Libya.

In times of political anarchy, Muslim orders constituted the only solid social framework, and actually shouldered some political and even governmental functions. In Ottoman Turkey, they imposed themselves on some weak or mystic sultans. Notably the Bektashi enjoyed a certain political importance in the Ottoman Empire. Primarily colonizing dervishes, in charge of Turkicization and Islamicization of countries conquered by the first Ottoman sultans, the Order of Bektashis was connected during the fourteenth century with the body of Janissaries, the elite army and instrument of Ottoman power. To what degree the rise of the Bektashi Order can be attributed to its links with the Janissaries is a matter still open for investigation as disagreement rages among specialists about the role of Bektashis in the formation of Janissaries as an elite army. It is considered, however, that the Bektashis constantly encouraged and dominated the Janissaries by traditionally providing their religious guides.

The existence of privileged links between Ottomans and Bektashis, as well as the presence of Bektashi dervishes at the sides of sultans at heroic times of conquest, gradually brought about the transformation of Ghazis and warrior dervishes into colonizing dervishes, propagators of Islamic faith. This explains why the first Ottoman sultans conferred on them the responsibility for channelling and bringing back under governmental control the heterodox groupings that were proliferating in Anatolia at this time. As the Janissaries were recruited from among Christian children converted to Islam and raised in Turkish circles, this also explains the rationale for attaching a dervish order to this armed force whose task it was to convert recently conquered countries to Islam. The Bektashis became thereby an instrument of Ottoman propaganda in these countries. One can therefore understand the reason for the expansion of the Order in the Balkans and Albania.

Bektashism was a popular, non-conformist doctrine representing a hodgepodge of many elements including not only Shiism and Sufism, but also anthropomorphic and cabalistic doctrines of Hurufism combined with an extremist Shiite credo that linked devotion to the divinity of Ali with beliefs in anthropomorphism, the manifestation of God in human form, and reincarnation and metempsychosis. All of these elements were concretions added to a substratum of ancient beliefs and pre-Islamic customs, including the symbolic value attached to the letters of the alphabet and some reminiscences of sun worship personified by Ali.

Despite its deep mystical roots, Bektashism is often depicted as a progressive current within Islam; one that is close to Westernizing and modernizing trends, and probably not unrelated to the Western Freemasons. This cleavage was to be strengthened in the aftermath of the official banning of the Order of Bektashis, following the abolition of the Janissary army in 1826. Bektashism was not annihilated, but resumed a more or less underground existence. Once reduced to a clandestine life, the Bektashis gradually drew closer to the Freemasons, with whom they shared the ideals of liberalism, non-conformism and 
anticlericalism. Under their influence, the Bektashi were to play the role of an enlightened intelligentsia, open to progressive ideas of all sorts. Most notably, they are supposed to have joined the French Franc-masonry, thanks to Fazli Bey, who under Voltaire's personal influence might have reorganized the Order so that it could later become the driving element of the Young Turk movement and develop close links with Turkish nationalism (Ramsaur 1942). Furthermore, the Bektashis have been permeable even to Marxist ideas during the 20th century, especially in Turkey.

One known characteristic of Bektashism is its adjustment to its surroundings to the point of assimilating local beliefs and customs. The essentially syncretic nature of Bektashism is most evident in Southeast Europe, where the Bektashis adopted certain Christian religious celebrations and worshipped some of their saints. Both Christians and Bektashis commonly frequented the same sanctuaries throughout Southeast Europe.

The Southeast European Bektashis are mostly found among the Turks of the Bulgarian Riviera, as well as in Dobroudja in the Rhodope Mountains, and the Muslims of Macedonia, Thessaly and Albania. They probably were influential in Bosnia, especially through the Janissary garrison that played an important role in the mid-18th century. In Bosnia, however, the vigorous promotion of Islam was successful in strengthening orthodoxy and fighting all kinds of unorthodox practices. It is generally agreed that heterodox orders like Bektashism could find no real possibility to be established in Bosnia, contrary to the situation in Albania and Macedonia (see Norris 1993: 101, 118). Those Bektashis present in Bosnia under the Ottoman Empire, and in an unorganized form under the Austro-Hungarian Empire, were of Albanian origin for the most part.

When the Janissaries revolted in 1826 and were subsequently put down by force, the Bektashi immigrated to Albanian territory, which became their favoured centre. Specialists have always noted that the highest Bektashi dignitaries, including the supreme leader of the Hadji Bektash tekke, were mostly of Albanian origin. Nowhere outside of Albania did Bektashism succeed in rallying as many adepts and believers, and when Turkey decreed the definitive abolition of all mystic orders in 1925, their general headquarters once again took refuge in Albania.

It is not difficult to explain how Bektashism spread so extensively among Albanians. If the Janissary army and the Bektashi Order were to be formally abolished, the abolition could only be effective in Istanbul, and even in Bosnia, as in all the provinces where the central Ottoman administration had direct authority and power. Yet Albanians remained outside these territories. The authority of the central Ottoman administration was insignificant in the Albanian area during this period, and the Bektashi continued to live there undisturbed.

\section{HETERODOX THEOLOGY AND NONCONFORMIST GROUPINGS}

Specialists in Islamic Studies know to what extent mystical Islam is specifically correlated to dualist and gnostic conceptions. Mysticism is primarily an intellectual process, and the experience of the mystic led to the formulation of various types of mystical philosophy, especially within Iranian Shiism (Corbin 1971, 1982, 1983). However, although this kind of theosophical doctrine belongs to the realm of speculative mystical theology, these spheres constantly percolated into the people's religion through the popular devotional manuals of the orders.

Bektashism essentially responded to the sphere of spiritual experience which ran parallel to the mainstream of Islamic consciousness deriving from prophetic revelation and comprehended within orthodox, codified, systematic theology (sheriat). In this need for a non-conformist religious experience there was no room for a clear-cut separation between man and the divinity, such as exists in the orthodox, legalist Sunni dogma. It represents the 
demand for a pantheist approach and a "warm" faith (Morozzo della Rocca 1990: 38). Bektashis see themselves as universal brothers. When mystical union with God is not quite the goal sought, it was the cult of the miracle-working saints, living or dead, through worship of their tombs that prevailed in their religious fervour.

In Bektashi conception, an analogy between human actions and the created world is reestablished, but also the analogy between moral actions and a world that should be denied, because for all Reality (hakikat) there is no existence but in the Truth (hakikat), which is in fact God (al-Hakk). Experienced as one Reality, for the Muslim mystic this is the world's foundation and its subsistence. Therefore everything in the world is nothing other than God, and this "hidden" aspect of the created world seems to have pantheistic connotations that are typical of the mainstream tradition in Bektashism (Birge 1937: 288-291). God is everywhere, in every animate and inanimate being, and his essence shows itself in all creatures.

For Bektashi, there are correspondences between the natural and the supernatural, and the universe is structured in a hierarchy starting from heaven and coming down on earth. Bektashism has deepened the correspondences between visible and invisible worlds, as well as those between human beings and the world. Bektashi tracts refer explicitly to the belief that the Divine is present in Man. Its signs are outwardly manifest in the shapes of a number of Arabic letters found in the human face and body. In this way, Man is created in the best of forms, because the same letters are used to write down the Revelation (Birge 1994[1937]: 282). Because the signs of the divine are found in the human face, the Bektashis hold it sacrilegious to touch the ground with one's face in prayer as the orthodox Sunni Muslims do.

Orthodox Islam in general is strictly monotheistic, but for the Bektashis, in particular, who clashed with official Islam at a very early date, one of the central beliefs is that the Imam Ali was a manifestation of the divine on earth. Ali, the son-in-law of the Prophet Muhammad, is one of the first Muslims and the one to whom Shiites attribute the revelation of mystic understanding of the Koran. For Bektashis, beliefs of reincarnation (tenassuh) and of God's manifestation in human form (tecelli) imply a belief in transformation and the multiplicity of forms. One of the divine manifestations - the Allah's mazhar, the perfect reflection of Godis realized notably in Ali, who represents the totality of the divine essence as an expression of perfect, divine beauty (Mélikoff 1998). The three letters of Ali's name are met in the face of every man and represent the shape of the face of God.

Muhammad was the bearer of devine 'light' while Ali was inspired by its mystical, 'lightened' knowledge. Ali is then held to be the originator (shahib-i risala) of the Koran, while Muhammad is referred to as the mouthpiece (natiq-i risala) of Ali. A different way of formulating this relationship is that the exoteric (zahir) aspect of the divine came into the world with Mohammad, while its esoteric (batin) aspect is identical with Ali. The Koran is the word of God corroborating the other revealed Books, just as the prophet Mohammad, the agent of revelation, is the last of a series of messengers of God starting with Adam and including, among others, Abraham, Moses and Jesus, viewed as a prophet among others. For the Bektashis, all the prophets and the Imams are reincarnations of Ali and it is understandable that in certain contexts, notably in Christian settings, Jesus (Hasreti Isa) is equated to Ali.

In other words, Muhammad and Ali are both manifestations of the same divine reality. In this way, Allah, Muhammad and Ali form a sort of Trinity (referred to as the ucler) manifesting one and the same Truth (hakikat), and thought of as a miraculous unity (tawhid). In Bektashi liturgical objects, pictorial art and theological tracts, as specialists give ample evidence (Birge 1937: 217; DeJong 1989), the trinity Allah-Muhammad-Ali is allimportant. Ali is always depicted in a hierarchically organized divine triad, miraculously unified with the Prophet and Allah, the supreme God. Even in everyday speech, Muhammad and Ali are understood as the same manifestation of, and identical to, the Divine, the ultimate Truth, hakikat. 
The importance to the Bektashis of the hierarchical divine triad is also reflected, among other instances, in the Albanian-American tekke of Michigan, in its being evidently displayed on a banner in the large public meeting room of the tekke (Trix 1993: 105). The banner hangs prominently between the Albanian and American flags directly behind the leader's chair. On the banner are verses from the Koran, translated into Albanian and written in white letters. In the corners of the banner are four names: Allah, Muhammad, Ali and Hadji Bektash. This contrasts with a common Sunni pattern by replicating the Bektashi chain of spiritual knowledge as an explicit keying and rejection of the Sunni pattern. If God's manifestation, the God's mazhar par excellence, is Ali who shows himself under various forms in Bektashi poetry and prose, numerous indications can be found testifying to the belief that the traditional founder of the Order appeared as Ali. According to Bektashi tradition, it was most important to address one's prayers to Ali at sunrise, while turning one's face to the sun (Birge 1937: 36). The association of the sun with the Divine, and thus with Ali, is not unusual in mainstream Bektashism. Modified versions of this belief might be considered a reformulation in Bektashi terms of a central tradition in Islamic mysticism: Ali is the source of the Divine light, which manifested itself in Hadji Bektash (DeJong 1989: 13). In other words, Hadji Bektash was also God in a different guise. The Bektashi silsila (hierarchical chains of spiritual revelation and power) came down indeed from God to the founder of the order, patron saint Hadji Bektash, and from him to every follower of Bektashis.

Regarding their organization, broadly speaking and aside from the peculiarities that may be accounted for by the political and economic systems of the countries in which they spread, the initial structures specific to heretic and heterodox movements remain rather indistinct. Their communities are suggestive of the early Christian groups of the first centuries, as described in the Acts of Apostles and the Epistles of Paul. Earlier Sufi and Bektashi groups also had been linked by enthusiasm, common devotions and methods of spiritual discipline, with the aim of stripping the soul and eliminating the self to attain vision of Reality (Trimingham 1971: 13). They were therefore integrated by spirit and aim rather than by any formal organization, and were in fact very loose organizations.

Significantly, the type of organization initially adopted by the first Muslim mystics led to the formation of more or less anarchical groups or circles of initiates, more or less closed and secret, who took no interest in sharing any collective discipline or dogma. At earlier stages, the master is not mentioned at all (Trimingham 1971: 167), even though respect for the spiritual freedom of each member necessitated regulations for the common life. The idea of a spiritual community was formed in such groups as a basis for their common life, and the master remained essentially a guide in spiritual matters, but not an autocrat of a convent, allegedly acting as an intermediary between believers and God.

Hadji Bektash himself, for instance, coming from East Anatolia, was a wandering hermit during most of his life. The description of his Vilâyetnâme corresponds to that of a wandering dervish, similar to Iranian Kalenders or Anatolian Abdals (Mélikoff 1998). The dervishes who followed him are called "Abdal" and from the very start, he is called "Pir" of Anatolian Abdals. Although he really existed, even referred to among the khalifa of Babaîs leader, he does not seem to have been a prominent character. He did not even seek to found any order, or to have had disciples during his lifetime. He remained the eponym of an order he did not found himself, quite unconscious of the impact he was going to have, his success being achieved after his death and in spite of him.

In the beginning, there were anarchistic groupings of a popular Sufism not yet clearly differentiated, especially as Bektashis were not the only heterodox brotherhood resulting from the Babaîs movement. Bektashism was only to become of real significance after having assimilated the others. Indeed, the principal heterodox groupings of Anatolia seem to have converged in Bektashism, which emerged from this popular, heterodox and anarchistic 
Sufism, mixed with influences of Islamized shamanism, Hurufism and early Eastern Christianity. If Hadji Bektash did give his name to the most popular order of dervishes in Anatolia, his worship developed well after his death (generally situated around the 1270s). Bektashism, on the other hand, was founded during the 14th century and was organized as a brotherhood only at the turn of the 16th century. The Order had to incur thereafter a progressive and even radical evolution. There remains probably very little resemblance between Turkmen popular beliefs of Hadji Bektash's time and those that form the heterodox but sophisticated doctrines of the Order of Bektashis.

Their initial dogged individualism led early Sufi and Bektashi groups to personal interpretations of the doctrines and traditions, with a tendency to reduce salvation and rebirth to a purely internal operation to the point of denying the need for rituals and rejecting any external display or collective worship. For Bektashis, worship is a secret affair, peculiar to initiates. They recognize no outside shape for the religion, and their heterodoxy resides in the non-observance of ritual prayers (namaz), they do not practise the five daily prayers or the ritual ablutions, nor do they observe the fast of Ramadan or believe in the necessity of the pilgrimage in Mecca. If they do affirm the importance of the Sunni injunction to pilgrimage, they understand true pilgrimage not as a physical journey to Mecca, but rather as a spiritual journey to the heart (Trix 1993: 34).

On a more formal level, they are criticized for their fanaticism and liberalism, tolerance of alcoholic beverages and the presence of women during ceremonies, as well as for indulging in orgies or sexual licenses and all the slanders of which eccentrics of all sorts had been the object during the centuries. The reproaches are identical to those that were formerly addressed against the Manicheans, the Cathars and the Gnostics - the same reproaches as all sorts of ignorantism tend to carry against any element foreign to the community. The Bektashis firmly believe that it is essential not to unveil the secret, that humans can know everything that God knows, and are responsible before God and not before their other fellow humans, that sin involves doing things surreptitiously rather than in public, and so on.

The Bektashi sense of human dignity extends similarly to women. For Bektashis, both men and women are equal representatives (vekil) of God. It was to a woman, who becomes "Ana" (Mother) of a community of Baciyan (Sisters), that Hadji Bektash transmitted his mystical teaching and powers. She transmitted all in her turn to her disciple, Abdal Musa, who in the first quarter of the 14th century perpetuated the memory of Saint Hadji Bektash by founding a first community of dervishes bearing his name (Mélikoff 1998). Bektashis always accepted women without veils to the meetings and initiated them as inner members of the Order alongside men. This acceptance of women has brought them criticism over the centuries and yet they have persisted in it. Frances Trix (1993: 149) believed that her current acceptance as student of a Bektashi master was certainly facilitated by the longstanding precedent of female disciples. Many mystical orders of Islam offered a religious sphere to women, little recognized in the legal religious set-up. Women could be enrolled as associates, they could be appointed as leaders to organize women's circles, and some even became dervishes, especially among Bektashis. However, most women found their religious focus in the local saint, and visitations to his tomb were the highlights of their religious life. The dualism between male and female religion was highlighted on Fridays when men went off to the mosque to display their communal solidarity by participation in ritual prayer while women were at the saint's tomb or graveyard making their offerings, and petitioning or communing with the spirit of the tomb (Trimingham 1971: 232).

In these conditions, the intensity of religious life prevails over its extension and salvation becomes a personal affair rather than a relationship with some grace-dispensing agency. Participation in the spiritual community comforted the individual need to oppose or transcend society, raising one temporarily into timeless supernatural experience. It was the function of 
heterodox movements, parallel and often in opposition to the orthodox instituted religion, to mediate to ordinary people the inner aspect of religious experience. Mystical orders embodied in themselves the whole mysterium fascinans of the age-revealed, esoteric, mystical and emotional religion.

In this way, Bektashism, as early Sufism, was a reaction against the external rationalization of religion in law and systematic theology, aiming at spiritual freedom whereby human intrinsic and intuitive spiritual senses could be allowed full scope. It was a subjective expression of personal religion in relation to the expression of religion as a communal matter. It was an assertion of a person's right to pursue a life of contemplation, seeking contact with the source of being and reality, over and against instituted religion as based on authority and legalistic morality. In the face of economic, social and ideological upheaval, the most radical mystics adopted attitudes cultivating distance from mainstream society. Their watchword is "ghurba", which is to say the desire to be an outsider (gharîb) in a world seen as corrupt and led astray by bad guides. Mystics of this sort are not simply opponents of the ruling classes. They are intent on going against social norms as well. In Albania, they were reputed to be bons vivants, heavy drinkers of raki (the local strong alcohol), courageous, democrats and believers in individual freedom.

\section{LEARNING FROM ISLAMIC MASTERS}

Viewed from these angles, the structure of Bektashi groups corresponds more or less to the types of religious organization conventionally known as "charismatic groups". This view may be reinforced by a reconsideration of Frances Trix's (1993) sociolinguistic study of the meanings of, and the means for, transmitting Islamic spirituality and worldview. The focus of her study is one lesson with an Albanian-American Islamic master, Baba Rexheb, leader of the Bektashi Order at the tekke of Detroit in Michigan. Trix's book, beyond the worthwhile and unquestionable methodological insights provided (for a full account, see Doja 2004), is centred on the structure of the learning process, not on the content of Sufi knowledge or the practice of mysticism and the meaning of relationships and activities usually implied. This is true even though Trix (1993: 11) refers to the "motif of sudden illumination" in the learning process: a phrase frequently used in the literature in reference to spiritual enlightenment and the "mystical union" of God and the seeker. Certainly she experienced a series of "sudden illuminations" in which she broke through to new levels of understanding of the process of learning with her master, of the relationship between them, and of what the ideal relationship between master and disciple is or must be. Yet if you are looking for a description of the transcendent union with God, and what it means for herself and her master, you will be disappointed. In that sense, as some of her reviewers have pointed out, her Spiritual Discourse is misleading.

I consider it interesting, however, to focus the discussion on the content of the object of her study, which is the meaning of the relations between master and disciple, since her main assumptions concern exactly this relationship. In other words, I would like to question the extent to which her conceptual framework and methodology, if adequately reconsidered, could provide a better understanding of Sufism and Bektashi religious conceptions in particular, and of mystical and heterodox orders in general. This understanding, in turn, could be conceptualized externally in terms of the societal, personal and ritual meanings it presumes. This seems important because the foundation of Bektashi and all Sufi orders is exactly the system of master and disciple. In Bektashi milieux, time is mostly spent making muhabet (talking with each other) and chanting or reading nefes (Bektashi spiritual hymns and poems). In this way, students learn how to be a talib (“one who seeks, who strives after"), the name given to the follower, the aspirant or the disciple of a murshid (the master, spiritual guide or, roughly, the "teacher") (Birge 1937: 96-97). 
Among Bektashis, the importance of the talib and murshid relationship is overriding. I have had the opportunity elsewhere to show that in Albanian society, the family name has often been derived from the name of one's own father or direct ancestor as well as of the village or town that the family came from (Doja 1998b), and how this feature became important for structuring the morphology of Albanian social organization (Doja 1999c). However, among Bektashis, the next identity frame is the name of one's murshid (Trix 1993: 75), and Hasluck (1929) has noted that Bektashi sheikhs were considered as family and clan chiefs (cf. Evans-Pritchard 1949). In the Bektashi world of discourse, in parables and narratives, poetry and nefes, the centrality of the relationship with the murshid is the norm. The murshid himself is also a talib (disciple), for each murshid is a talib of his own murshid.

Frances Trix, before becoming an assistant and now an associate professor of anthropology at Wayne State University, had been a talib for twenty years, learning Bektashism and probably aiming to become a Bektashi, from her own Albanian Bektashi murshid. The basic analogy of her study evolved into the learning in the relationship of talib to murshid similar to the learning of a language, with language understood as personally linked games, the main game being the sharing of nefes, the linkages of which have theological significance. In nefes, this "breath of spirit", the feelings and devotion toward one's particular murshid are endlessly evoked and elaborated. Frances Trix believed the nefes could thus be seen as a particular Bektashi language of talib-murshid relationship. The Bektashis consider the power of a nefes to be the actualization of the relationship with the murshid, for the inspiration to compose a nefes comes from one's own murshid.

An important issue mentioned in Trix's book is the fact that the Albanian spiritual master repeatedly made the point for his talib (Frances Trix, in this instance) that Sunni Islam considers the relationship of human beings to God as a direct one "without intermediary". The critical message was that Bektashism, by contrast to orthodox Islam and Christianity, adheres strongly to the belief in intermediaries between humans and God-the murshid being such an intermediary. The build-up to this message was first a quick likening of Christianity to Sunni Islam, and an equally swift contrasting of these forms with Sufi Islam. The new understanding that emerged reinforced the message of the murshid being an intermediary, and more specifically, an intercessor. Through many connections, by repeatedly telling and retelling narratives and adages, chanting nefes and making muhabet, the understanding of the message that the murshid is the intermediary between human beings and God is evoked, reformulated and memorably forged throughout Frances Trix's book (see, e.g., Trix 1993: 33, 69-70, 95, 120-125, 127, 131, 151). This in turn gives the talib an expanded understanding of the murshid, both as intercessor and as agent of inspiration.

Frances Trix's experiences as a talib can be used to examine the extent to which the murshid-talib relationship contributes to an understanding of Bektashi cultural models. Her story, gracefully and humbly told, is not so much a discourse-oriented ethnography of learning or a sociolinguistic illustration of mysticism, but above all a text that illuminates the process of an interpersonal encounter. Overall, what is being passed on is not facts but a relationship and a communication, for the relationship and communication between seeker and master "mirrors" that of humans and God. In this sense, although Trix's primary aim is not to describe the mystical experience and its social significance, her study gives an intimate and detailed account of the steps that she herself has taken on the Sufi path as led by her master. As such, her study is a rare application of linguistic anthropology to the transmission of spiritual knowledge that makes a significant contribution to our general understanding of Sufism. Her statements are particularly interesting from both points of view: that of the talib learning spiritual knowledge from her own murshid, and that of the anthropologist interpreting this knowledge and writing about culture from a scholarly perspective. 
One of the functions of religion as a social system, especially in Christianity and Islam, is to serve as a mediating cultural system of representation between powerless earthly creatures and an all-powerful God located in heaven. Mediation makes it possible for the heavenly divinity to intercede on behalf of humans on earth. Muslims, and in particular apologists of Sufism, assert that their Islam is more than religion and articulate its techniques and masterdisciple relations as reflections of those of God to humans; indeed, these assertions are commonly met with a more social or political ontology.

Definitely, in the case of Bektashism, the difference for the talib lies in the presence of the murshid as the intermediary between humans and God; while in the case of orthodox Islam or Christianity, the relationship is seen as a direct one without intermediary. Frances Trix, as a talib, could not but view the relationship in this way. The learning framework and the position of talib offered her a vague yet all-encompassing scheme in which every narrative and adage must be placed according to theological explanations. In addition, the teaching process Trix describes is not an over common occurrence in daily life, but rather part of those rare instances when one is faced with publicly producing the type of intellectual explanation for which daily life does not normally call. Baba Rexheb, the same Albanian Islamic master teaching anthropologist Frances Trix, has managed to publish a number of intellectual speculations concerning Bektashism. Anyone who has read them is observing a counterpart of what such super-informants as Ogotemmeli or Muchona, as probably all anthropologists know, can manage to do with ideological schemes when their prestige is at stake. This is still nothing more than what Maurice Bloch (1985) calls the expansion of ideology into something which misleadingly looks like an interpretation of the world.

Unfortunately, Frances Trix, as an anthropologist, seems unable to recognize a different meaning for her relationship as a talib other than that advanced by Bektashi ideology. This brings to the forefront what anthropologists know as the danger of "going native", which refers to the possibility of becoming over-involved with the people being studied to the point of losing the detachment that is essential for the role of analyst. When linguists and anthropologists are analyzing discourse and making ethnography, it is certainly not merely for the sake of an exclusive self-reflexive methodology and discoursing verbal flow. I strongly believe that by using different kinds of research methods for writing and talking about culture and cultural content, the scope of anthropology as a discipline, be it linguistic or political, should be after all a search for cultural meanings and understandings.

For a talib, the message of the murshid as an intermediary between humans and God is well assessed and clearly understood. Yet, what is lacking in Trix's case is the anthropological intuition that would enable her to recognize the exact meaning of Bektashi conception about the relationship between humans and God. According to Trix and all apologists of Sufism and Bektashism, the difference between heterodox Bektashism and orthodox Islam and Christianity must be in the Sufi and Bektashi hierarchical, intermediary organizational structure between humans and God through the transmission of mystical gnosis from one's murshid. This amounts to saying that in the case of orthodox Islam and Christianity there is an absence of such a communication or, put another way, that there is a presence of a direct, unmediated communication between humans and God.

It is clear that the relationship between talib and murshid is particularly relevant for understanding Bektashi religious conceptions, but a critical examination of this relationship can be an outstanding opportunity for arguing exactly the opposite of what Bektashi ideology attempts to put forward. As long as heterodox theology developed from common experience of both spiritual knowledge and suffering, it is possible to understand how covenantal structures of divine mediation corresponding to specific stages of Bektashism and Sufism gain a different meaning if the intermediary hierarchy is found in the conceptualization of the divinity or in the organization of the worldly, human society. 
Normally in Bektashi world, for a murshid to speak for someone does not mean he would put words in his mouth when speaking to other men, but implies speaking to God for one (Trix 1993: 123). When in these narratives the point is clearly made that "the murshid is the way through which the student reaches God", this is because the murshid has already acquired the stage of the Perfect Man (insan-i kamil); in other words, the capacity to communicate directly with God, and the talib has not yet. God could respond to the murshid if called upon, but not yet to the talib, because "if both called out to God, then that would signify separation between them, and to whom should God respond?" (Trix 1993: 122). In fact, the talib is still a follower, though encouraged to pass through the gateways of ultimate Truth (hakikat), and in his or her turn, to become perfect and to reach his or her own union with God (tawhid).

Even though apparently the murshid is acting for the talib as a simple "intercession" (Trix 1993: 123), this is the same as all that one sees or writes in spiritual matters is in-come, inspiration from God through one's murshid. Especially nefes are such in-come from the murshid. In Bektashi terms, inspiration in poetry comes from the heart, which is the seat of higher faculties of perception, and it is brought to the heart by either God or one's murshid (Trix 1993: 127). In other words, here too, the murshid seems to be not only a simple intermediary: "Before, I had understood it as the means to reach God, but now with the added example of inspiration I could see that it meant to receive from God as well" (Trix 1993: 124; emphasis added). Thus, the learning process of attunement with the master as the mystical union with God is one and the same ultimate goal, as well as the means to that goal.

The Sufi term "ilham" (generally translated as "inspiration") is, in Bektashi usage, near in meaning to personal "revelation", and contrasts with exoteric impersonal prophetic revelation (Trimingham 1971: 145). The esoteric knowledge that the Bektashi murshids possess has come to them, not by genealogical progression, but by spiritual progression. In fact, it came to them by a twofold action of God, by transmission from Muhammad, through a chain of elect masters, and also by direct inspiration from God.

For Bektashis, then, the experience of spiritual learning is achieved by means of the murshid as a communication process with the spiritual knowledge. Had this process led to possession of the mystical gnosis (marifat), as normally expected in the very "faithful" sense of the experience, the novice might have been sanctified as a potential saint, in a mystic union with God (tawhid). However, the union, involving divine inspiration, would not be possible without progressive communication through different conceptions of divinity split into a series of hierarchical emanations. The most accessible of these is in fact nobody else than one's own master, who appears to be not an intermediary between humans and God but rather God in a different guise. In addition, the repeated $h u$ at the end of nefes lines can refer either to God or to one's murshid through whom God is invoked. $\mathrm{Hu}$ is both a name of God, in the Muslim sense that God is referred to by $h u$ ("He") in the Koran, and can refer indirectly to one's murshid.

From her master, Frances Trix learned that in Bektashi conception there are explicit hierarchical series or chains ( silsila) all connecting back to Cennabi Hakk (the term for God). The reason given by her master is that "Cenabi Hakk could not always stay and guide humankind, so he sent the following people in his place: Cenabi Hakk/khalifa/prophet/veliler (saints)/tarikat (Sufi Orders)/murshid" (Trix 1993: 102-103). Some hierarchical chains reveal even more specifically the hierarchy of spiritual revelation and hence of spiritual or supernatural powers of the saints. "The power to perform miracles comes through: Cenabi Hakk/Cebrail (Gabriel)/Muhammad/Ali/the imams/Saint Hadji Bektash/the murshid/" (Trix 1993: 103). The divine series are quasi-historical chains in that the prophets are understood to have ended with the coming of Muhammad, and the tarikat or Sufi Orders to appear much later. In mentioning Ali, the place of the mystic revelation, characteristic of the Bektashis, is specifically emphasized. As for the saints, "some are hidden, some are known" (Trix 1993: 
103). In other words, they can be considered differently according to the hierarchical chains of spiritual revelation or power.

The developed silsila embraced two divisions. For Bektashis, one chain of authority benediction included an unbroken historical line of talibs and murshids through which they connect themselves to the founder of the order, their patron saint Hadji Bektash. This unbroken chain of spiritual, divine initiation of talibs and murshids continues the link from the order-founder to earlier saints, to the imams, and back to Hussein, whose murshid was Ali, whose murshid was the Prophet Muhammad, whose murshid was the Angel Gabriel, and thus to God. Building on this continuity, Bektashis come into relation with God through devotion to their personal murshid.

Frances Trix (1993: 103) viewed both divine and historical chains connecting to God in Bektashi conception exactly as "a sort of logic in that its function is to display connections and thereby to legitimise the place of the murshid cosmologically". At the end of her book is an epilogue, in which a famous 13th-century murshid tells his own talib story "conveying in one page what I have taken many to suggest," wrote Trix (1993: 147) very modestly indeed. I think the story, well-known in Sufi milieus, is worth retelling:

It seems that one day Rumi [the talib] went to his murshid's house. But when he arrived, he found that Tabrizi [the murshid] had just left. Rumi quickly looked down the narrow streets and saw the coattails of his master as he turned into an alley. He followed his murshid. Yet whenever he got near, Tabrizi was just turning another corner in the twisting streets. Finally Tabrizi went into a house, and Rumi followed him in. But once inside he did not see his master anywhere, so he went up on the flat roof. But he did not see him on the roofs either. So he jumped off, and his murshid caught him in his arms. (as told in Trix 1993: 158)

Following Edmund Leach (1972), I have argued elsewhere (Doja 2000b) that the significance of understanding the communication between humans and God lies in the fact that the hierarchical model of religious mediation corresponds to the dogma of orthodox faiths, while the model in which all hierarchies are denied, in its real embodiments, is closely linked to millenarian and mystical beliefs and to the development of heresies and heterodoxies such as those related to Bektashism. The former model may well support an established, hierarchical power, whereas the latter corresponds to an oppressed or deprived minority, seeking justification of its revolt against the established authorities. According to this model, the establishment of a political hierarchy within society goes hand in hand with the insertion of a unified conception of divinity (i.e., a pure monotheism within the theological system). On the other hand, a visible hierarchical conception of the divinity goes along with egalitarian politics in society. The conception of a relational equality, derived from the idea that people are equal in their relations with the divinity, is effectively present alongside an ideology of substantial egalitarianism among human beings.

Clearly, in the former model there are mediators between humans and God, the murshid, for instance, or a priest or sacrificer, acting as a representative of the secular congregation, who places themselves on a higher plane than the latter but in a position of inferiority with respect to the deity. By contrast, the mediational structure of the latter model is necessarily of another type, and claims to be the negation of hierarchy of any sort. The initiative must be entirely in the hands of the divinity, which manifests itself in a number of hierarchized emanations, but without any mediation, by dispensing the gifts of its grace on the faithful, with believers receiving direct, immediate inspiration. Charisma, divine grace and spiritual knowledge touch them without the help of any intermediary, and are in no way affected by any ritual or specific expertise, more or less efficient, performed or controlled by a mediating priest or murshid. Viewed from this angle, the system of beliefs and practices related to Bektashism is a kind of liberation theology that makes it possible to meet social, cultural and national perspectives. 


\section{INTELLECTUAL SPECULATIONS AND NATIONALIST PROJECTS}

In the context of Bektashism and Shiite Islam, a founding value is attributed to the drama of Karbala, where the Imam Hussein, son of Ali and grandson of Muhammad, was killed in 680AD. Bektashis, like all Shiite Muslims (Ayoub 1978), put great emphasis on keeping alive the memory of this tragic event through epic poetry, plays, processions, commemorative services and other mnemonic devices. The rituals of commemoration of Hussein's martyrdom, the use of very direct language and imagery, the re-enactment of suffering and the constant repetition of ideas serve as a basis for identity and cohesion of the community (Norris 1993: 171-174).

The well-known 19th-century Albanian poet Naim Frashëri also retells the saga of Shiism in a monumental, epic poem of twenty-five cantos entitled Qerbelaja, which was first published in 1898. By relating to this seemingly religious but political confrontation, Naim Frashëri, following a longstanding tradition of Eastern literature and philosophy, tried to realize and promote his illuminist and humanist liberating ideas. He praised the justice of the Imam as the standard-bearer and champion of liberation against the injustice of the tyrant and usurper adversaries, while declaring as an inexorable principle the conclusion that in the battle between justice and injustice, liberation and tyranny, the final outcome shows justice and liberation victorious. More than a retelling of historical events, Qerbelaja is a moralistic and intellectual record, it is a reformulation and promulgation of humanist morality and principles, an appeal for moral purity and perfection, for humankind to be able to enjoy earthly life and confront its reversal (cf. Xholi 1998).

Nevertheless, in actualizing the events, to what all Naim Frashëri's poetic and moral speculations normally lead, the Battle of Karbala is thought of as the Albanian fight against Ottoman power and that, in their battle, the Albanians would win since justice was on their side. In the last canto of his opus, Frashëri suddenly forgets the drama of Karbala and keeps talking exclusively about Albanian national issues: propagation of language, learning and education, the need for union, gentleness and fraternity for Albanians. You even may sense that all 24 previous cantos are only written for bringing about in the last one: the Albanians and the Albanian question. For Frashëri, the meaning of the battle becomes as much human salvation as national liberation. Actually, his Bektashi epic has to be judged in the context of his greatest poetic aspiration, the History of Skanderbeg, which is another monumental epic in which Frashëri narrates the exploits, successes and failures of the Albanian national hero against the Ottoman invaders. Even though both were published the same year and were written on the same style, one grounded on Muslim mythology and Eastern mysticism, the other on Classic mythology and Christian symbolism, it is only the latter epic that became the poem of Albanian national pride.

Naim Frashëri was one of the most eminent thinkers and leading figures of Albanian Bektashism, Albanian romanticism and the Albanian national movement. In the formulation and argumentation of nationalist ideology, he made use of both religious and realist, pantheist and gnostic conceptions, coming from both Eastern and Western traditions. Among other things, he openly suggested and theorized the reconciliation of religion with the idea of the nation.

Yet, even though in his oeuvre and inspiration an important place is taken by religion, its dogma, terminology and conceptual devices, even though he continually addresses God as the divine, supernatural power in explaining everything related to human being and life, Frashëri's rationale was of humanist and nationalist interest. In his worldview, religious conceptions have no special role independent of his rationalist, humanist and nationalist ideology. He often writes about, and takes any opportunity for mentioning, God, but very freely and even giving the divine a role in the liberating movement and national education 
of Albanians. The martyrs of Karbala, quite contrary to historical evidence and Eastern tradition, owe much to the heroism of the romantic era, including Frashëri's own poetic portray of Skanderberg (Norris 1993: 182). While in Qerbelaja, events and characters gain moral verisimilitude in the way that beliefs of good and evil are transmitted by Shiite and Bektashi oral tradition, Frashëri uses them to give shape to the system of values that constitute the core of all his poetic and intellectual oeuvre. Cloaking the discourse in religious dress, Frashëri aimed to promote his nationalist ideas, and elements of the divine were not necessarily religious convictions but very often used as metaphors of worldly and national values, merely religious wordings but easily acceptable from the masses.

Some specialists in the area, probably limited by the narrow contours of the very object of their studies, hastily and uncritically present the construction of the Albanian nation as an offspring emanating exclusively from Bektashism. It is not the case here to redeploy the history and character of Albanian nationalism (Doja 1999a, 1999b, 2000a) nor the politics of religions in the reconstruction of Albanian identity (Doja 2000c), but this view is definitely an exaggeration, and frankly aberrant. When Nathalie Clayer (1992: 300), for instance, wonders in a "naturally legitimate" way why particular links existed between Bektashism and Albanian nationalism - more exactly, "why this brotherhood offered nationalists a privileged framework in the Albanian society of the time" and "why there were no other structures able to help the nationalist movement"- this is a clear statement that could not stem from a specialist having even a minimal knowledge of the Albanian situation. By the same token, I wonder whether she is able to understand what a religious movement could be and how it could be explained in sociological or any terms. All of this is in spite of her particularly energetic zeal in accumulating masses of documentary information on Muslim brotherhoods in Albania (Clayer 1990) or throughout Southeast Europe (Clayer 1994).

Similarly, it is an exaggeration to argue, as Duijzings (2000: 167) does, that Naim Frashëri has attempted to bridge the religious divide of Albanians by proposing Bektashism as the national religion of Albanians. This view seems to stem from an uncritical reliance on secondary compilations of literary histories (e.g., Mann 1955; Elsie 1995) found throughout Duijzings's book (for a full account, see Doja 2004). As a matter of fact, this belief seems simply impossible and even quite absurd to those with a minimal knowledge of the Albanian context. The Bektashis, in spite of their concentration in Albania, were a small minority quite marginalized within Albanian society, especially before the spread of the national movement. Naim Frashëri was certainly not blind to this fact. The relationship of religion and national ideas in Frashëri's conceptions has very often been uncritically investigated by scholars camped on both sides of either religious or nationalist lines. There is reason to believe, however, that Naim Frashëri did not intend so much to provide Albanians with a unique religion, but rather to make nationalist ideas successfully acceptable to Albanians of whatever religious affiliation.

The problem, however, is not so much whether this has been, as Duijzings argues, a failed attempt to bridge the religious divide between Albanians by promoting a secular national cause that incorporates some heterodox Bektashi elements within it. Taking Naim Frashëri's epic reproduction of the Battle of Karbala and situating it on comparative grounds with such a state- and church-produced body of literature that recreates and embellishes the Kosovo Battle mythology in Serbia, as Duijzings (2000: 157-202) does, is in itself a problematic issue in methodological and analytical terms. Duijzings finds both have much in common: each have been portrayed through epic song and folk verse, both record a lost battle where righteous forces were overcome by evil ones, and the main hero was sacrificed, leading to the necessity for followers to accept suffering as a step to redemption and a revolt against tyranny. For the most part, Duijzings believes both lent similar weight to the growth of Albanian and Serbian nationalisms respectively during the 19th century. 
Still, as some of his reviewers point out, excepting the partly religious nature of both myths, they cannot be compared, either in terms of content or their elaboration and diffusion. Duijzings recognizes the lack of a deeply rooted cultural tradition as the reason for the failure of Naim Frashëri's epic to become a political symbol in Albanian nationalism. By contrast, what has made the Kosovo Battle myth so extremely powerful is its being rooted in folklorism and the church culture of Serbian nationalism. In his chapter on the Serbian folkepic of Kosovo, Duijzings (2000: 176-202) has understood it well in this way. Although the Kosovo myth was created in Serbia and never resonated in Kosovo itself, throughout the 20th century it provided Serbs with a set of roles with which to sort out into proper categories ambiguous or overlapping identities in Kosovo.

The Serbian Kosovo myth and epic poetry grew out of a long elaboration of oral and church traditions; their religious content was closely tied to the culture harboured by the Orthodox Church-a powerful institution always influential in Serbian nationalist ideology. Actually, even after the downfall of communism and federalism in Yugoslavia, the Serbian Orthodox Church revitalized nationalism by carrying Lazar's bones around Serbia for reconsecration. Relations between church and state were enormously strengthened. Even the military murderers were transformed into heroes through epic songs, a process aptly labelled as "gusle laundering" (Duijzings 2000: 199), while Serb paramilitary leaders were compared to Milosh Obilic, the main hero of the Kosovo Battle. ${ }^{1}$

The tendency to equate Serbian and Albanian nationalisms is not only unjustified, but is actually a dangerous ambush in which Serbian nationalist agitators are still trying to entrap public and scholar opinions. In fact, the political instrumentality of the Serbian myths of the Battle of Kosovo is not exactly commensurable with Naim Frashëri's Qerbelaja, but rather with other types of political folklorism and pseudo-culturalist projects, serving either chauvinistically or ideologically charged nationalisms. Examples of this sort could be found, for instance, in the communist propaganda of Eastern and Central Europe when cultural and folkloric traditions have been instrumental in justifying and magnifying the "authentic" foundations of the political and ideological regime (as I have shown elsewhere for the case of communist Albania, see Doja 1998a). Other anthropologists have suggested a similar argument (e.g., Gossiaux 1995). Another parallel with the Serbian Kosovo mythologies can be found in Hitler's propaganda campaign of the 1930s and early 1940s when German Volkskunde traditions were instrumental in promoting the sinisterly reputed Nazi ideology. To compare Frashëri's national ideology to Serbian nationalism, as Duijzings does, is like comparing Herder to Hitler.

On the other hand, while the Battle of Kosovo was instrumental for Serbian nationalism as the mythologizing and embellishment of a local, historical and factual reality, Naim Frashëri uses the drama of Karbala as a local and historical metaphor of a mythical and ethical worldview. In this sense, the relational parallel between Albanian and Serbian national ideology, if any, seems to be in difference instead of similarity. There are two different, opposed conceptualizations that give way, after instrumental transformations, to a number of single utterances that share some similar details in style and content, but are irrelevant for any relational comparison. When you compare such single utterances then, you do not compare them on a superficial, linear one-to-one basis, but only with respect to their relative setting in the whole field of constructed nationalisms and their relative difference or similarity with all other relevant actual occurrences within the same field. Both types of transformations are variants of the same pattern, but there are differences in the form and content of their conceptualization of prerequisites and outcomes.

What is lacking here is the analytical and anthropological insight to understand that the poetic and intellectual speculations of Naim Frashëri, retelling the saga of Shiism as the religion of victims of persecution, are relevant because they have been instrumental in 
shaping theological ideas with gnostic and dualist conceptions. Even though specialists in the literature can argue that "Bektashi texts in general are relatively silent on points of social ethics" (DeJong 1989: 10), anthropologists, after Clifford Geertz (1973), know very well how dualist conceptions and liberating theologies develop from the idea of suffering. This is explicitly articulated in Naim Frashëri's Qerbelaja, as similar Christian hierarchical symbols are in his History of Skanderbeg. The evil exists from the origins, having its own cosmological and anthropological consistency of which no explanation is attempted, but a strong assertion is given without any margin of ambiguity:

The good and the evil, God and the devil, the heaven and hell, and all other things that exist are not other but human. So the ancient sages have said, all have been clearly separated from the origin; you can take the part that you wish, you can choose either the Imam Hussein or Jezid and Maviye; one get you the salvation, and the other the perdition. (Qerbelaja XIII: 448-459; my translation)

In the drama of Karbala, the imam endures a divinization process that fulfils, so to speak, a function of "encouragement" of the liberation fight, of escape from the evil and the world in which it is inscribed. And this is because the mysterium iniquitatis that renders the world and the worldly life "repugnant" (Qerbelaja XIV: 27) is unassailably at the forefront. The power of God therefore endures an obvious limitation, justifying a suspicion of either impotence or malice. Would it be possible, and therefore necessary, to interpret this "malicious God" as the second god of dualist print (Guidetti 1998)? In Bektashi conceptions, the world is clearly separated into good and evil, as humankind is divided into the oppressed and the oppressors. Satan is held to be actually incarnated, for Bektashis, in the person of Yezid, the enemy of Ali, and in his offspring. It is not difficult therefore to assume a painful fight of liberation of the spirit from the worldly imprisonment, which is exactly for what "strikes the heart of the gnosis" (Bianchi 1983: 15).

It is my contention, therefore, that it is this dualist character, together with pantheist conceptions, that might have reasonably made it possible for the Bektashi religion to join with Albanian national ideology. Indeed, it would be necessary to argue this link, especially by the analysis of the organizational and theological character of Bektashism as a mystical, heterodox order throughout its historical transformations. Only to the extent of the articulation of contest and liberation ideologies with hierarchization of covenantal structures of divine mediation, can we understand not only the special "failed" relation of Bektashi religion to Albanian nationalism through Naim Frashëri's poem Qerbelaja, but also the difficulty in explaining why Albanian nationalism generally lacked strong religious attachments.

\section{LIBERATION IDEOLOGY AND ETHNICIZED RELIGION}

Issues of Bektashi heterodoxy have been always politicized and ethnicized, in Ottoman as well as in modern Turkey, depending on different contexts and the course of events. Bektashis were perceived from very early on as dissidents and were often persecuted. Treating them as a Sufi Order, in the early 16th century, the Ottoman authorities perceived the Bektashis as an internal threat to the stability of the Empire because of their purported loyalty to the Shiite Persians and the monarch of the Safavid state-the Ottoman enemy of the time. Characteristically, the fate of Bektashis in 1826, when the Order was suppressed, is normally attributed to the link with the Janissaries, who were dissolved in that year. From a religious point of view, Bektashism was characterized by its syncretistic nature; they were strongly opposed to legalist and orthodox Sunni Islam. From the social point of view, they were characterized by their marginality, their nonconformist attitudes and their refusal to recognize the established order. 
In the Balkans, and especially in Albanian territory, a number of decisive turns had been taken that replicated in some ways the overall history of Bektashism. Much earlier, before the Ottoman authorities had officially abolished the order in 1826, the growth of Bektashism arrived at its highpoint in Albania, especially when the Bektashi developed close links with the secessionist efforts of Ali Pasha of Tepelena, who had entered into dispute with Ottoman authority in order to gain recognition for an autonomous administrative entity. Ali Pasha had gained considerable success, following the example set by his contemporary Muhammad-Ali Pasha in Egypt, in establishing and strengthening a local administration that had recognised his authority in southern and central Albania. By embracing Bektashism, which called for Shiite revenge against Sunni powers, he was able to engage in a war, both national and religious, against Ottoman dominance. However, following the defeat of Ali Pasha in 1822, the Ottoman state undertook a ruthless purge of Bektashis, which might have compelled the sect to find itself in opposition. Henceforth, they embarked on a prolonged resistance to Ottoman power. Later again, during the difficult history of assertion of the Albanian national identity, when a great number of Albanian Muslims, despite their "divided loyalty" (Skendi 1967: 469-470), often firmly expressed the desire to sever links with the Ottoman Empire (see Bartl 1968), the political position of the Bektashis is particularly revealing. The wellknown heterodoxy and tendency to assimilate external elements enabled Bektashism to fully integrate nationalism into its doctrine and made it extraordinarily popular in Albania.

The Bektashi's traditionally difficult relationships with the religious and political Ottoman authorities certainly contributed to their choice of anti-Turk and nationalist stance (Morozzo della Rocca 1990), but this went along with a reinforcement of liberation heterodoxy characteristic of their system of beliefs and practices. An important fact is that Bektashi conceptions, in Albanian context more than elsewhere, would appear heterodox and heretical as much as for Sunni Islam as for Twelver Shiism, to whose tradition they are often supposed to be related. At a critical period in the development of doctrine and organizational structure, Albanian Bektashis showed, much more than any other Sufi or Shiite order or other Bektashis elsewhere, that esoteric knowledge was not a privilege exclusive to a particular genealogical lineage but acquired by spiritual progression, thanks to a divine grace freely and directly bestowed.

It is certainly not surprising that it was Naim Frashëri that explained, and to some extent founded, in his Bektashi Pages (1896; published in English translation by Hasluck 1929: 552-563), the novel theological and practical principles of Bektashism and the organizational rules governing its functioning. In matters of theological doctrine, he even rejected the authority of the Koran, the sacred book of Islam. Pantheism in Bektashism is also acknowledged and even furthered by Naim Frashëri, although the application of this term is anathema to many Sufis. In a number of works, surpassing pantheist conceptions evolved in mainstream Bektashism, he stressed in unusual way that the book of Bektashis is their faith in the Universe, and especially in human beings, since the true faith is written nowhere, not in any book either, but rather is in their heart. Furthermore, the absence of any fanaticism and dogmatism are characteristic features of Naim Frashëri's Bektashism (see Xholi 1998).

Naim Frashëri's argument of the Universe as the lively representation of God was another way of stating materialist and realist principles, in particular with his conception of an infinite soul unified with nature and waiting for special conditions in order to materialize itself into the infinite variety of things of the world (Shkëndijë e diellit ndaj manushaqes). Frashëri, free of any fanaticism and dogmatism, brought about with his oeuvre a new conception of the divine, in sharp contrast to orthodox Koranic Islam and much more heretical than heterodox Bektashism. Although relying on Bektashi conceptions that locate the letters of Revelation and the signs of Zodiac in Man (Birge 1994[1937]: 282), his teaching does not cast Man as a microcosm reflecting the macrocosm, but rather presents the cosmos as a projection of 
Man. For Naim Frashëri, the real believer should know that God is not in the heavens, but inside the human heart: "I was looking everywhere to find God, the great God of Truth; it was inside me, myself I had it inside" (Lulet $e$ Verës).

By taking God from heaven down to earth, the divine, included and unified in nature, has no power other than to materialize itself into the infinite variety of things of the world, and hence to become available to knowing. God is no longer a secret power far away from the human world, but a power that shows itself at any moment, one that human beings can see and know, approach and reach (Parajsa dhe fjalë fluturake). God is identified with humans as well as with that divinely created environment that manifests God's own nature. The ancient heritage of Islamic esoteric knowledge (al-batin) is forcibly re-expressed in Frashëri's conviction that one may know the nature of divinity within one's own being, body and, especially, beauty of visage. The features of human being are the mirror of divinity: "When God first sought to show his face, he made mankind his dwelling place. One who knows one's inward mind knows that God is the mankind" (Njeriu).

Everybody's human life is therefore an individualization of the natural infinite soul, while death is the individual part going back to its primary source- "Light going back to Light" (Qerbelaja VI: 65) - for it becomes a regeneration of natural life. In Frashëri's conception of immortality there is no heaven and hell, divine damnation and reward, but simply a worldly life with human beings at its centre, where heaven and hell are all together, always in permanent and uninterrupted renewing, transformation and regeneration (Lulet e Verës; Qerbelaja XI). In an unusual development of heterodox Bektashi conceptions, for Frashëri, metempsychosis and life after death is neither promise of recompense nor threat of condemnation, but simply guarantees the transmission of human and national values from the past to the future.

The distinct conceptions of the divine and its attributes according to separate religions, emphasized by different rituals and institutions, brought near divisions among Albanians. In contrast, Naim Frashëri claimed that true Muslims do not necessarily need a mosque and that Arabic and Persian, the languages of the Prophet or the Imams, though especially intended for religious practice, are not convenient for Albanians. "With pray and ritual you cannot find God, neither with Lent nor blessing, as do who don't know. And you priests and hadjis forget church and mosque, for church and mosque cannot be but where God really is" (Lulet $e$ Verës). His heretical teachings excluded any ritual or institution, aiming toward the political intention of eliminating all dividing elements. God cannot be that of separate religions, but that of pantheism, included and unified as it is into Nature and Universe.

In Naim Frashëri's poems, in particular, Sufi mysticism is blended with a nature pantheism centred on the Albanian homeland. Frashëri's pantheism was an original theological conception especially elaborated with an exemplary conviction within the social conditions of Albanian national movement. In his verse, the Albanian homeland became part of the divine scheme. Yet, his non-sectarian, interfaith and national appeal is not only a personal characteristic of his own and fellow nationalists, but is also expressed in typically gnostic and heterodox terms (Norris 1993: 164-165). His heretical and pantheist conceptions, close to the universal pantheism of Spinoza, the romanticism of Goethe and Schiller and the rationalism of Voltaire, aimed to provide the theoretical foundation of the Albanian national movement. Even though often formulated in Bektashi and Sufi terms, Frashëri's pantheism was strengthened in its social content and intentional tendency as an expression of contest in opposition to Sunni orthodoxy and its Ottoman stronghold and, hence, as an ideological argument for promoting the liberating and emancipatory ideas of the Albanian national movement.

Naim Frashëri was not a unique leader, but the quality of his verse, together with his other nationalist and educational activities, placed him at the forefront of the avant-garde of the Albanian national movement. He became the defender of Bektashism not merely because of 
any personal special link or conviction, but because by means of Bektashism he could better proclaim his contest credo in opposition to Ottoman occupation. As long as Ottoman political power coincided in ideological level to Islamic religion, all deviation from dogmatic and orthodox Islam was assumed to take on a political meaning of opposition. By the same token, by voluntarily putting forward and even developing this very character, he aimed to bring Bektashism closer to his own theory of nationalism. To this extent, Albanian nationalism could not be perceived by any means as the offspring of Bektashism, as Clayer (1992) believes, but rather the other way around. It seems reasonable indeed to consider that it is the new Albanian Bektashism, especially after the influential elaboration of its heretical doctrines instilled by Naim Frashëri, that might have become the offspring of the Albanian national movement. The only thing is that, in turn, Bektashism was often idealized as one of embodiments of the Albanian Volksgeist.

The fact that for Bektashis there are no universal shrines as there are universal saints - the latter being commemorated by local shrines-led to a localized rooting and ethnic regionalism of religion contrasting with the universal Shiite and Sunni places of pilgrimage. As Bektashism came to represent an alternative form of Islam, more liberal and less formal than orthodox Sunni Islam close to the authorities, especially in Albanian territory, it probably did much to create and preserve this remarkable religious tolerance so particular to Albanians (Filipovic 1954), which adapted itself easily to the national and patriarchal sentiments of the Albanian race, and to the traditions and customs of the local population. In fact, as long as the heretical heterodoxy is exacerbated in the context of national ideology, Bektashi nonconformist stance, while quite traditional, does not fail to manifest itself any time and any where even nowadays.

French scholar Irène Mélikoff has carried out extensive work on Bektashism and for a long time has maintained, as she tells us in the introduction to her most recent book (Mélikoff 1998: xx), that alongside the popular doctrine, there was also an urban cultivated branch that cut itself off, more or less, from the more popular elements. According to her earlier opinion, a cleavage developed and widened over the centuries between Bektashism as a more organized order, practiced in the urban centres, and Alevism, which remained in a rural, essentially popular environment. In both cases, the beliefs are the same and the same nefes are sung during ceremonies. The differences are mostly of a social character. The Bektashi tekke, built near the urban centres, were attended by cultivated people, whereas the Alevi tekke were only attended by the masses, generally uneducated and of former nomadic origin, and this difference was to be increasingly clear-cut, especially during the 19th century.

However, most historical evidence points to the Bektashis, at least in the Balkans, as mostly recruited from among the lower class Christians converted to Islam in the cities and countryside. In Albania, Kosovo and Macedonia in particular, the oldest Bektashi tekke have been built in the mountains and the countryside, far away from urban centres and travelling routes (cf. Rexhepagiqi 1999: 210), much in the same way as in early Christian monastic life. Fortunately, in her recent book, Mélikoff (1998) followed more consequently her main thesis of Bektashism as a syncretistic and gnostic religious movement, which always incorporated local beliefs and practices. In the Balkans, it integrated Christian ideas, and in East Anatolia, it merged with Iranian and Kurdish elements. This new way of considering the problem drove her to recant the differences of an essentially social nature between Bektashis and Alevis she had previously conceded.

Bektashis, as well as Alevis, now belong to the same popular environment. They represent lower class, essentially semi-nomad or recently settled and rural populations, as opposed to upper class urban populations. Certainly, there were cultivated Bektashis living in urban centres including those that followed progressive movements, poets, writers, intellectuals, and even politicians. In Albania as well, a high proportion of Bektashis were intellectuals, 
shopkeepers and craftspeople. The reputation of Bektashism also attracted some very wealthy magnates, even ulemas and viziers, but in general, the milieu of Bektashis was almost exclusively peasants. Bektashis, as Alevis, are affiliated to the same popular Islam, heterodox and nonconformist. They preserved the same background of beliefs and practices. According to Mélikoff's recent opinion, what distinguishes them is the geographical context in which they evolved separately: Thrace and the Balkans for Bektashis, and Anatolia for Alevis.

However, while I understand that this perception of Alevism as a form of Bektashism is quite correct, the process by which it occurred is by no means self-evident for rejecting all differences in social terms in favour of only geographical ones. It is certainly not at all accurate to assert that the term "Alevism" is "inexact and does not correspond to any historical reality". An Alevi, as understood in Iran, is literally a descendent of Ali. Yet in Turkey, the term "Alevi" replaced, at a relatively recent date, that of "Kizilbash", which applied to the partisans of the first Safavides, and has taken the pejorative meaning of "heretical rebel". At present, the term "Alevi" tends to take the same meaning, although the majority of Alevis are Turks. In present-day Turkey, the term "Kurdish" is also very often used to a certain extent, not only in an ethnic sense, but also with a sense of social discrimination. It indicates the Anatolian living in a certain way, to whom tribal membership is still alive and who professes or practices a heterodox Islam (Mélikoff 1998).

The same phenomenon happened in the past even to the Turks themselves. The sentiment of nationality appeared only very late among Turks, with Pan-Turkism at the end of the 19th century. When tribal Turkmen were converted to Islam, the term "Turkish" took a pejorative sense - that of ill-mannered people. An opposition developed among the Ottomans converted to Islam, mainly an urban privileged class, and the nomads or the semi-nomads, still badly or not yet fully Islamicized. The former were "Muslims", the latter were simply "Turks".

The shifting from one term to another within the same religious and ideological tradition, though showing at first glance local and regional inscriptions, uncovers an implicit difference toward official, political or religious power. When power relations are marked by hostility, people feel pushed to adopt a resistance to identity building and suffering discrimination along ethnicized lines. However, it is evident (and this explains to some extent Mélikoff's long-lasting but illuminating misinterpretation) that these affiliations are open to continuously negotiation and change. Every heterodox or heretical religious grouping may experience different and opposing characteristics in the course of its evolution.

It is not surprising, therefore, that the term "Bektashi" tends to be replaced by "Alevi", especially in the context of heterodox Islam in Turkey, where Alevi claims are currently becoming an expression of Kurdish nationalism, which tends to present Alevism as a form of Kurdish religion, especially in its most non-conformist and gnostic variant. As Turkish political culture is not any more defined by Sunni orthodoxy but by strong anti-nationalist and anti-communist tendencies, local Alevi identity has come to infuse both Kurdish aspirations and Marxist-Leninist inspirations (Bumke 1979). A similar situation, cloaking political and social conflicts in ethnic-religious dress, is still to be found either between Bosnian ulemas and Albanian dervishes, or between Muslim Albanians and Christian Serbs in former Yugoslavia and Kosovo, respectively.

Though religion constitutes just one factor among many that contribute to the development of a sense of belonging to a larger group, most identity scholars consider it an identity marker that divides one group from another. The practice of religion, like any cultural marker, is a ritual linked to the historical contingencies of a particular moment. Religious practices in the Balkans have shifted over time, altering the definitions of group identity. Duijzings's (2000: 106-131) work is particularly useful in deconstructing the notion of a monolithic Islamic identity in the region. By tracing the internal divisions between the Albanian dervish orders and the Bosnian ulemas (the officially sanctioned Islamic Association) in the former Yugoslavia, he shows that 
what specialists of the literature call "Balkan Islam" (Popovic 1986; Bougarel and Clayer 2001 ) is instead manifested in a complicated variety of expressions that give rise to a number of identities. Duijzings (2000: 159) reminds us that for Albanians "religion is almost irrelevant in official political life"; that Albanian nationalism is not clothed in religious terms; and that Kosovo's Muslims were never supported by Muslims from elsewhere in the Balkans. This challenges the notion that knowing an individual's religious identity would facilitate placing that person within a given ethnic identification or conflict.

Duijzings draws attention to the political realities exacerbating the differences between religious groups in former Yugoslavia. First and foremost, he documents a split among Muslims in Kosovo between those who turn toward Sarajevo as the centre for religious guidance, and those who do not. The former are often referred to as "Muslim Slavs" associated with Bosnian Muslims to the north; they speak Serbian as their mother tongue and do not consider themselves to be ethnically Albanian. There is a second split among Muslims along the confessional Sunni/Shiite divide. Yet, Sunni Islam is associated with the Muslim Slavs of Sarajevo. The Islamic Association wielded all the political power from Sarajevo, while the dervish orders were largely based in underdeveloped rural areas that fared badly at the end of the Balkan wars and conclusion of both World Wars. Not surprisingly, Kosovo sheikhs conducted open polemics in the 1970s and resisted efforts by Sarajevo Islamic authorities to weaken the dervish orders in Kosovo (Rexhepagiqi 1999: 137-138). These polemics only subsided when federal state authorities intervened in 1979. The fact that Bosnian Muslims generally preferred to marry Bosnian Croats or Serbs instead of Albanian Muslims is symptomatic of the same state of affairs.

If some specialists in the area consider the opposition between an Albanian popular Sufism in Kosovo and a Slavic orthodox Sunni Islam in Bosnia as a "distorted caricature", the contradictions are indeed deeply rooted, far beyond this specialism caught in a mixture of literalism and a dreadful specimen of statisticizing which means absolutely nothing. They have rather a political, social and moral significance, which is in turn better expressed in ethnic or religious discourses. As Bosnian Muslims held privileged positions regarding Islamic matters under the Yugoslav system, the proliferation of Sufism in Kosovo can be interpreted as an attempt by Albanian Muslims to reassert their autonomy in the religious sphere.

As long as the character of Bektashism and all Sufi or Shiite groupings of Islam display, in their religious structure and theological doctrines, a cultural system corresponding to the model of hierarchical conceptions of the divinity together with a model of religious mediation in which all hierarchies are denied, it is not difficult to assume that their counterpart will be the rejection of all real political and/or ethnic hierarchies in social life and human relationships, which in turn makes it possible for liberation theology and national ideology to meet. In discourses related to Muslim religious revival, be it confraternal or otherwise, one recurrently finds nationalist motives that better illustrate the necessity of considering such a powerful mobilizing force in the role that religious leaders claim they play in this field.

\section{ORGANIZATIONAL TRANSFORMATIONS}

Normally, Sufi and Bektashi groups are inspired by the ideal of a community of the spiritually pure gifted with graces and powers that knowledge is supposed to procure, and called upon to dispense the benefits around them. A dividing line splits followers into two classes depending upon whether they are capable or worthy of receiving some or all of the gifts of grace and spirit; some people having acquired them and possessing them fully, while others aspire to partake of them, or are just at the beginning. 
Since all preached moral prescriptions could not be observed literally and to the same extent by all, Sufism only demanded that the best of followers be strict in their practices. It was obliged therefore to resort to the definition of a sort of dual ethics, establishing two distinct systems of observances and rules of conduct. A liberal one was conceded out of sheer tolerance to the weakest and most imperfect "seeker" or "follower". Another, much stricter, was reserved to an elite, also known as "perfects" or "saints" (të mbërrimët), who belonged to the superior class of the elect few. Each of the religious groups, and each of the communities of which they were composed, contained members of both sorts, more or less grouped and divided into two classes, with the larger of the two (the followers or muhibs) being organized and subordinated to the other (the elected few or dervishes). At the top are the saints, almost sacred, below whom are the sinners, or at the least, the profane, the lay people still under the sway of the world and its temptations.

The opposition between the elect and followers is akin to that between the old and the young, the strong and the weak, the perfect and the imperfect, the spiritually accomplished and the novice, the murshid and the talib. However, their distance should not be exaggerated, at least at the beginning. Aside from the fact that seekers are supposed to have received both the faith and knowledge when they entered the religion, they are acknowledged as true believers and, like the elect, they are an integral part of the Order. The talibs become muhibs with the latter being called "dervishes" when they have given proof of their strict observance and their wisdom. It is through the elect, however, thanks to the contacts and concrete ties created and maintained with them through almsgiving, services rendered and aid provided, that seekers and followers form and strengthen the bonds that attach them to the body of their religion, while at the same time they acquire merits and edify themselves.

At this point, for the masters of the Ways, the mystical tendency becomes highly dangerous as an individual experience since there can be mystic Ways to gods other than God. Hence the insistence upon the necessity for guidance under an experienced director. The potential for perfection is present in every human being, since God is present in everyone. However, in order to reach the stage of the Perfect Man (insan-i kamil), to go through the Gateways of spiritual growth and to experience the divine Reality and ultimate Truth (hakikat) and penetrate to their inner significance (Birge 1937: 102-103), one needs a guide, a spiritual master (namely, the murshid) who has himself reached the perfection stage of insan-i kamil (Birge 1937: 96-97). For Bektashis, if each human being is a mosque, each human face is the face of perfection (vech-i kamil) of one's murshid. In him, the outer signs of perfection are matched by inner perfection and the dual, inseparable personality of Muhammad-Ali was believed by the Albanian Bektashis to be represented on earth by every murshid who is thereby entitled to great veneration (Norris 1993: 97). For this reason, Bektashis equate ritual prayer (namaz) with paying visits to one's murshid. It is this shift in morality, related to a radical change that took place in the Sufi and Bektashi environment, that, according to Trimingham (1971), corresponds to the overriding importance of the system of murshid-talib relationship, which becomes the very foundation of the Orders.

In an extended Bektashi adage, it is asserted that a talib is one who "knows that he or she does not know" (Trix 1993: 86). This refers, of course, to more than facts, for when Bektashis in general speak of knowledge, they mean spiritual knowledge (i.e., coming closer to God). For the lowly Bektashi talib, however, what is lacking is a framework for understanding what is going on. More generally, the Bektashi goal for the talib "to know what one does not know" refers of course to spiritual knowledge, but as Trix herself admits, also to an acknowledgement that one is unable to predict sequences and find meaning within a new situation. In other words, and in Goffman's (1974) terms, knowing of one's not knowing is a sort of suspension of the frame of experience. In the interaction, this lack of frame, this "not knowing", is reflected in features often characterized as differential strategies between 
negative and positive experiences, both an attempt to maintain and to reduce social distance. Thus, if the Bektashi tradition expects and promotes this suspension of frame for the talib, its sense should be the point of an actualization of the relationship with a murshid, as a kind of "negative experience" allowing reintegration into some other frame. In Bektashi meaning, the way to achieve the spiritual goal is understood through the murshid, who serves as "the only way to a reintegration, thus the knowing of one's not knowing cuts one loose and focuses trust on the murshid" (Trix 1993: 103).

The murshid carries on with the guidance of individual talibs, but even though in this stage the master appears quite naturally as the medium between God and humans, in a later stage the right of the individual is denied, not merely to seek a Way by trial and error, but even under guidance, for the murshid is the mediator, and the allotting of spiritual tasks becomes a mechanical process. The talib's initiation involves the surrender of his will to that of the murshid. Although Sufism is the embodiment of mystical experience, its distinctive feature becomes the very fact that "knowledge" of the divine is only transmitted through the murshid.

Therefore, the situation of the talib seeking "to know what one does not know" could be considered, with Trix (1993: 89) a strong understanding that it is only through the murshid that light and assistance may be gained. Every act of knowing brings forth a world, and all knowing is effective action as the power of all discourse is the potential to disclose a world. Therefore, in Ricoeur's (1981: 182-183) terms, "to understand is not to project oneself into the text; it is to receive an enlarged self from the apprehension of proposed worlds which are the genuine object of interpretation". This view squares well with the Bektashi vision of spiritual knowing as the action of drawing closer to God. In Bektashi's terms the "enlarged self" would include the spiritual realm. Yet instead of speaking of an "enlarged self", Bektashis speak of "loss of self" of "death before dying", which mean a dying to this world and its values as a goal to reach annulment in, and mystical union with, God.

These seemingly contradictory metaphors should not mask Ricoeur's (1981: 182-193) insistence that any event of interpretation is an appropriation (Aneignung), which means to make one's own what was initially alien. What the talib "makes his or her own" is not something mental, nor is it some design supposedly hidden behind spirituality. Rather, it is the projection of a world, the proposal of a mode of being in the world, that the murshid discloses by means of non-ostentatious references. Far from considering that the murshid, who already masters his own being in the world, projects the a priori of his own understanding and interpolates this a priori in the talib, the appropriation is rather a process by which the revelation of new modes of being and new forms of life gives the talib new capacities for knowing. If the reference of discourse is the projection of a spiritual world closer to the world of God, then it is not in the first instance the talib who is projected in this world. The talib's capacity for projection is only broadened by receiving still new modes of being from the murshid.

In this sense, the Bektashi vision of spiritual knowing as the action of drawing closer to God is fundamentally an experience of spiritual growth in which one receives, but does not control or direct. The Bektashi expression of "loss of self" partly reflects the precariousness of trusting the Unknown, as well as the reframing and restructuring of the experience that can ensue. In turn, the murshid nurtures the relationship with the talib, but always with a clear sense of who has the knowledge. Knowledge thereby becomes the prime source of power, given the potential of Foucault (1980) for helping us to understand social relations.

The organization of what cannot properly be organized-personal mystical life-arose naturally through the need for guidance and association with kindred aspirants. However, 
through cult-mysticism, the individual creative freedom of the follower was fettered and subjected to conformity and collective experience. Guidance under the earlier masters had not compromized the spiritual liberty of the seeker, but the final phase involving subjection to the arbitrary will of the perfects turned him or her into a spiritual slave, not into God, but into a human being, albeit one of God's elect.

Changes took place in the meaning of Sufi terms as well. "Awareness", "contemplation" and "meditation" by degrees acquired new meanings, until they came to signify, in the orders, participation in the being of what is being contemplated: God, Muhammad or one's murshid, living or dead (Trimingham 1971: 146-148). Hence, the meaning of terminology degenerated from relationship to God to relationship to a dead saint or living murshid, becoming now the medium between God and human beings. "Mental concentration" (tawajjuh), for example, came to mean the spiritual assistance rendered by the saint to his devotees or by the murshid to his talib. In this exercise, like the attempt to contact the spirit of the dead saint, the murshid concentrated upon the talib, picturing the spinning of a line of linkage between his pineal heart and the heart of the talib through which power could flow. At the same time, the talib concentrated upon becoming a passive vessel for the inflowing power of the murshid.

In most Bektashi narratives, the point is clearly made that "the murshid is the way through which the student reaches God" (Trix 1993: 121). In one of these narratives, the murshid commanded his talib to swim across the water with him, holding onto his collard and all the time saying "Pir Hakk!" ("the Pir (patron saint, here murshid) is the Truth"). The talib, however, showed his lack of trust in the murshid by reconsidering halfway across the water and calling out to God instead, at which point he began to drown. In his explanation, the master made clear that it was murshid's place to call out to Cenabi Hakk (the Bektashi term for God) for both of them. As for the talib, his place was to call out only to the murshid.

The theological rationalization of the necessary relationship between talib and murshid was articulated through the historical aspect of the divine hierarchical chain, called "silsila", that was already available in the theological conceptions of the Orders. At first sight, as Trix (1993: 103) has showed, both divine and historical chains connecting to God in the Bektashi conception may be deemed as a sort of logic to legitimize the place of murshid cosmologically. Yet, in fact, given the excessive proliferation of Orders and their ramifications in almost any local setting (cf. Halimi 2000: 76), there is good reason to believe that the first concern of the founder and leaders of an Order's branch in their attempt to gain personal ascendancy, was to demonstrate that they had followed the course of a well-known Sufi. They could then use the authority of this master and all the transmissory links right back to the first Caliphs for their teaching and practice. It is this chain of authority or mystical transmission that is called "silsila", which became nothing but a means to assert the new doctrinal orthodoxy of the Order. As new ideas were fostered on eminent Sufis of past ages in order to make these ideas respectable, so the silsila provided a doctrinal and power line going back to these "rightly-guided ones".

Religious scholars normally present three successive stages of development in Sufism (e.g. Izeti 2001: 30-34): from asceticism (zuhd) to mysticism (tasavvuf) and then to corporatism (tarikat), which Trimingham (1971: 102-104) characterized as the individual surrendering to God, surrendering to a rule in the next phase, and finally surrendering to a person. In the first stage, the master and his circle of pupils were frequently itinerant, having minimum regulations for living a common life, leading to the formation of undifferentiated, unspecialized lodges and convents. Methods of contemplation and exercises for the inducement of ecstasy were individualistic and communal. In the second stage, the transmission of a doctrine, rule and method corresponded to new types of collectivistic methods for inducing ecstasy. Deriving from professed illuminates, the development of 
continuative teaching schools of mysticism (silsila-tarikat) conformed and made docile the mystical spirit within organized Sufism to the standards of tradition and legalism. In the third stage, the transmission of an allegiance alongside the doctrine and rule formed new foundations branching into numerous "corporations" or "orders", fully incorporated with the saint veneration cult.

Significantly enough, as time went on, the organizational system of the Bektashi Order was increasingly replaced by another one that was more sophisticated and much more institutional and hierarchical. The distinction between talibs and murshids was maintained, but the subordination of the former to the latter is now emphasized. In addition, both talibs and murshids simply became the last two ranks of a hierarchy containing a number of other additional grades, added to the two previously existing ones by superposition, or more accurately, an order with two classes was replaced by a much more complex one. Finally, under specific political conditions, the internal organization of Bektashism developed into a centralized ecclesiastic hierarchy. Starting with the hierarchically lower level, the class of ordinary people and potential followers were categorized as muhibs. The immediate superior class included the elect, righteous and truly initiated dervishes or të mbërrimët, who became babas, religious leaders hierarchically recognized. The whole organization is now headed by a single leader, the grand-dede or kryegjysh (literally "head-grandfather"), supported by leading figures known as khalifa. Centralization was even pushed to the extreme, as the headgrandfather, legitimate heir and terrestrial representative of God, acts in some way as the supreme pontiff of the holy religion. Master among the masters, he embodies all of the spiritual power, and is supposed to lead and govern followers by making sure the dogmas are maintained and transmitted, discipline and tradition are respected, and orthodoxy is upheld.

Out of the diverse heritages of heterodox Islamic tendencies and Christian Anatolian and Turkish superstitions, the Bektashi Order was very nebulous at first. It became a hierarchical institution, highly organized and centralized, especially while linked to the powerful military body of Janissaries. The officials of the Order approached nearer to a clergy class than any other in Islam, while the tekke provided a parochial village religion, with a system of lodges, in many respects equivalent to the diocesan church system. The murshid ceased to teach directly, but delegated authority both to teach and to initiate to representatives (khalifa). A special cult surrounded the murshid's person, associated with the power emanating from the founder-saint of the order. He became the spiritual heir of the founder, whose qualities and powers become inherent in him upon his succession.

A new aura now emanates from the murshid as a protégé (wali) of God, which eventually, in this stage, became belief in his mediumship and intercessory status with God. The Bektashi life of recollection and meditation is now increasingly associated with a line of ascription, which bestowed the Order, its formulae and symbols, as from the master and guided by all disciples along his Way in his name. The change, as in early Sufism, came with development of the collegium pietatis into a collegium initiati whose members ascribed themselves to their initiator and his spiritual ancestry, and were prepared to follow his Way and transmit it to future generations.

In this way, the Order attained its final form of organization and spiritual exercises. Innovations are fully integrated, and their spirit and aims are stereotyped. No further development is possible and no further work of mystical insight that could mark a new point of departure in either doctrine or practice can make its appearance. The authoritarian principle is a chief feature, along with veneration for the master, inheritor of the divine mystical wisdom, and utter subjection to his authority. The development of organization embodied a hierarchical principle, with a general range of uniformity, an elaborate initiation ceremony and disciplinary principles, solitude, fasting and other austerities for adepts. 


\section{POLITICAL REVERSAL}

As political conditions change and the organization of religious structures undergo a number of transformations, the essential differences between hierarchical and unified types of theology, acting as mediating cultural systems of representation between humans and God, change and adapt accordingly. Nevertheless, both sociological conceptions of the role of religious faith, orthodoxy and liberation, are not mutually exclusive or essentially contradictory, by any means. There are not two concrete kinds of behaviour, nor is there a merely "routinization" process in the Weberian sense (Weber 1978[1922]: 246-254), but rather a process of dialectic change and transformation.

If the character of Bektashism and all Sufi or Shiite groupings of Islam showed first a cultural system corresponding to the model of religious mediation in which all hierarchies are denied, when the members of the previously persecuted religious minority have already acquired a degree of religious and political respectability within society at large, the subjective and millenarian doctrines of heterodoxy and liberation theology fade into the background. In the end, chances are that the heirs of mystics and the heterodox promoters of spiritual reform and social movement will turn into followers and faithful defenders of a legitimate authority. They will become the spokespeople for an institutionalized orthodoxy whose support will be sought by the political regime. The implication of change in theological conceptions in support of either liberating social and national movements or in the re-establishment of a new political power in human society may be illustrated by the further development of Bektashism in the political context.

The hierarchical and centralized organization corresponded to a doctrinal radicalism every time the Order approached the establishment of orthodox political powers. In these conditions, the mystical content of the Order weakened. Bektashi leaders were seeking to subject the mystical element to Islamic standards, to make mysticism innocuous by tolerating much of its outer aspects and forms in return for submission. Order leaders vied with one another in demonstrating their loyalty and subservience to legalistic Islam, and in the process Bektashism was emptied of its essential elements and left with the empty husks of mystical terminology, disciplines and exercises.

According to Trimingham (1971: 67-104), the transformation of Sufi companionships into initiatory colleges began with the Sunni triumphs over Shiite dynasties that coincided with the foundation of the Ottoman Empire. Bektashism also finds its final form at the beginning of 16th century. It left its larval state to take the form that has characterized it since, when the efforts made by Ottomans to organize the Order by making Hadji Bektash the patron of the Janissary body was dictated by the need for disciplining these movements and bringing them back under government control. Before becoming the champions of Sunni Islam, the Ottomans, like all Turkmen tribes, passed necessarily through a period of assimilation of heterodox Islam, which corresponded with a period of social, political and military crisis. In particular, the last episodes of Hadji Bektash's Vilâyetnâme are not only naive, but confused, seeking to gain the approval of the reigning dynasty and to attach to it the Turkmen popular saint that become the eponym of the Order of Bektashis. Already in the 15th century, this Order of dervishes was actually protected by the Ottoman dynasty, having been granted significant endowment (Beldiceanu-Steinherr 1991) and on the point of being considered, paradoxically perhaps, the state religious order.

According to Hasluck (1929: 482-493), Hadji Bektash might have acquired its reputation "by usurpation" and has nothing to do with the doctrines of the Order which bears his name. Bektash could have been in the beginning a simple tribal name that was exploited later by the Hurufi-Bektashi sect and arbitrarily adopted by the Janissaries. The legend concerning the foundation of the Janissary body by the Sultan Orkhan and his attachment to Hadji Bektash 
might have been only the "intrigues" of Bektashis aimed at appropriating the organization of Janissaries, while recognizing Hadji Bektash as their patron saint and the Order as their spiritual ally.

In contrast to Hasluck, modern specialists remain sceptical toward the interpretation of the legend of Abdal Musa, the dervish who accompanied the Sultan Orkhan during his conquest of Bursa in 1326 and thereafter perpetuated the memory of Hadji Bektash by founding a first community of dervishes bearing his name. Irene Mélikoff (1998: 93) maintains that to consider the attachment of the name of Hadji Bektash to the Janissary body as Bektashi "intrigues" is to seriously underestimate, at the time of heroic conquests, the importance of the Ottomans and the absolute power of their dynasty. I believe, however, that the problem is not underestimating Ottoman power, but rather one should consider the conditions by which the "intrigues" were made possible in the shared political interest of both the Bektashis and the Ottomans.

It is certainly not a mere coincidence than once again, according to the legend, in the early 16th century, Sultan Bayazid invited Balim Sultan, the Bektashi leader at the time, to be his guest, and the Sultan himself with high officials of the court joined the Bektashi order. In turn, it was this emblematic personage, considered as the second major leader in the history of the order, that made determined efforts to reform its organization and the practice of its members, apparently because both of which had succumbed to unorthodox practices and rituals. Bektashism, thereafter, in the peak of its heydays during the 17th century, maintaining a strong central organization, with affiliated village groups limited to Anatolia and its European provinces, even claimed to be a Sunni order (Trimingham 1971: 80; Norris 1993: 89). However, it was in fact very unorthodox and regarded as a Shiite Order due to its reverence for the House of Ali. The fact that the Bektashis were rarely attacked on grounds of doctrine or innovations is directly related to their association with the Janissaries and the Ottoman authority. In turn, the officials of the Order clearly gave their loyalty to the Sunna of the Prophet as a necessary stage in their code of discipline.

Transformations of this kind are clearly evidenced, especially among Albanian Bektashis. From the pioneering documentary account by Birge (1937), it can be shown that earlier Bektashi were concerned with ascetic-mystical theory and with illuminating, almost poetically, their search and the states they experienced. In turn, the change towards greater systematization is seen in the manuals being produced as guides for initiation, which became particularly important for understanding the theological significance and social experience of Bektashi religiosity. While the earliest manuals of this nature could be found among Sufi Orders as far back as the 11th century, the most popular are found very late, especially during the 18th and 19th centuries. From Albanian Bektashis, however, two 17th-century manuscripts written in Turkish are known. ${ }^{2}$ It is interesting to note how the language of these manuscripts, in contrast with both earlier and later manuals, is wrapped in the flowery Sunni orthodox vocabulary, often ambiguous, but appearing sometimes as a forced disguise to all outward appearances of Sunni orthodoxy (Guidetti 1998: 264). In fact, from the 17th-century texts to the 19th-century epic poem Qerbelaja, for instance, there is a progression from an effort to comply with the dogma of orthodox Sunni Islam to features of a categorically Sufi and Shiite nature. Beyond the hierarchical development of their internal organization, discursive interactions in Bektashi narratives, poetry and adages actually show a coherence of linkages progressing from the outer to inward - that is, from a more Sunni or orthodox Islam to the decidedly mystic Sufi conceptions (cf. Trix 1993: 33-34). I believe the explanation of these two different attitudes is to be found in the historical and political conditions of Albania in the respective periods of the texts' composition.

In the 17th century, as political power in the Ottoman world was overwhelmingly in the hands of orthodox Muslims, Sunni images were the grounds of legitimacy. Sufism or Islamic 
mysticism could then progress only from the outer Sunni form to an inner Sufi meaning. When they do affirm, for example, the importance of Sunni injunction to rituals, fasting and pilgrimage, they understand true rituals of namaz not as mere superficial practice but rather esoteric symbols of justice and goodness, giving emphasis to sincerity of faith and not to the religion's outward observances. They take true fast of Ramadan not as exempt of material food but rather a spiritual cleaning of heart from the evil, and true pilgrimage not a physical journey to Mecca but rather a spiritual journey to the heart. The Bektashi world of discourse can be seen as a legitimizing strategy in which a later relationship, not sanctioned by Orthodox Islam, seeks legitimacy by being related to one of the basic relationships of Islam. In the same way, the order of describing the hierarchical chains in which the Bektashi conception of divinity is structured parallels again the outer to inward paradigms from the more general Sufi to the more particular Bektashi. On the other hand, by the end of the 19th century (Qerbelaja was published in 1898), the imperial authority was in decline and Albania was already vibrating with desires for independence, to which Naim Frashëri himself was deeply dedicated.

Then again, it is precisely in Albania that the development of Bektashism arrived at its highpoint. During the Ottoman period, Bektashis in Albania and in southern parts of former Yugoslavia benefited from political hegemony and many Christian sanctuaries fell into their hands. Especially under the political patronage of Ali Pasha of Tepelena (1790-1822), Bektashi leaders benefited from new opportunities and the order enlarged its following considerably. In turn, Ali Pasha embraced and supported Bektashism because of a growing sympathy towards its later ideological and organisational development, which might have been instrumental for backing his general policy. Indeed, Bektashi dervishes might have served him as diplomatic agents (Bartl 1968: 104-105), and he used their organization and religious doctrine to win popular support and occupy new territories, to increase his power, widen his political influence, and consolidate his independence from the central Ottoman authorities.

During the national movement in Albania, a great number of Bektashi leaders, in spite of a short-lived alliance with the Young Turks, firmly adopted nationalist ideas. Through their nationalist action, the Bektashis acquired considerable prestige and popularity, and an aura that extended to both Christian and Muslim portions of the population, especially in the southernmost regions. The number of Bektashi tekke more than doubled at the time, even though most of the new followers were attracted mainly by the nationalist ideas or simply by the desire to learn to read and write at the tekke. While many joined the Bektashis in religious terms, they also wanted to join the nationalist camp, for nationalism had become a fullyfledged part of the doctrine of Albanian Bektashis.

On the eve of Albanian independence, the Bektashis were numerically important and politically influential. It was under the political patronage of independent Albania, however, that Albanian Bektashism, recognized by the highest governmental authorities, came to be a nationally and internationally structured ecclesiastic institution. The seat of head-grandfather, the supreme pontiff of the Bektashis, was transferred to Albania after all mystical orders were banned from Turkey in 1925. Furthermore, the Bektashis had an institutionally recognized representative in the highest function of the state. The High Council of the Regency of independent Albania was composed of four, rather than three members, representing each of the country's denominations: Sunni Muslims, Orthodox Christians, Catholics and Bektashis.

In this way, Albanian Bektashis ceased to be considered conventional members of Islam and were regarded, rather, as an independent religious denomination. The organization of the Order also became increasingly structured, improving its methods of recruitment of followers and the appointment of its hierarchy. More than any other Sufi Order, the Bektashis obeyed a rigorous and severe rank of hierarchy and the whole system of tekkes was hierarchically ranked in relation to each other (cf. Halimi 2000), which militated to increasingly concentrate 
rich endowment of estates. Because of explicit political circumstances, as specialists have shown through abundant documentary evidence (Clayer 1990: 47-67), the hierarchical pattern of the organizational structure of Bektashism in Albania reached a very peculiar expression not only in terminological, local terms, but also in a more sophisticated and clearcut ecclesiastical as well as political hierarchy, which perhaps surpassed limits observed in Ottoman context.

National activists, in their ideological educational and programmatic tracts, like Naim Frashëri's Bektashi Pages and, in particular, his brother Sami Frashëri's famous and muchwork on "what Albania was, what it is, and what will become of it" (Shqipëria ç'ka qënë, ç'është dhe ç'do të bëhetë), already have charted the transformation of the hierarchical structure of Albanian Bektashism into a political party organization, with its own aspirations to power and its own special authority. This ideological evolution of Bektashism in Albania was to run parallel with another development that overtook the order in connection with its organization. Bektashism, in the reality of independent Albania actually adopted a hierarchical organization in which the rank held by a member is graded and his status conformed to his seniority and the proportion and degree of his commitment and loyalty. In other words, here again the final stage of the hierarchical and centralized organization coincided with the establishment of orthodox religious and political power. As generally within Sufism in similar conditions, conformity to the legal establishment began from the moment the religious Bektashis leaders felt the need to support their statements with prophetic sayings, and when they felt it necessary to express conformity with the revealed Law of orthodox Islam (shariat). Bektashi leaders now increasingly strive in reprimanding several colorations of mysticism and fanaticism, trying to bring followers back to more respect for fundamental Islamic rules. They vigorously reject criticism that the Order and its doctrines are against the beliefs of Islam and that Bektashi dervishes make only prejudice to Islam, hiving themselves off from the genuine Islamic teachings (see Rexhepagiqi 1999: 258). Religious scholars, in particular, warn against the belief in the incarnation of God in human form, the transcendental annulment in God, and the cult-mysticism mistaking the murshid for the God. They try to defend Bektashism from all accusations of heterodoxy or liberalism and consider it identical with the normal understandings of legalist Sunni Islam, stressing its missionary role and transmissory links militating against doctrinal deviations of any kind. While they admit marginal heterodox and nonconformist influences or that Bektashism might have been "misused and misunderstood by destabilizing forces and currents hostile to Islam society during 19th century", which did cause its disgrace in 1826, they argue "the Order that had enjoyed the full support of Ottoman power until that time cannot be thought without the fundamental values of Islam", the spiritual way of tarikat going necessarily through the legal gate of shariat (Izeti 2001: 53-55).

Starting from the period of independent Albania, representatives of the hierarchy of Albanian Bektashi clergy reacted against assertions that often tended to consider the order of Bektashis as a doctrine of strong heterodoxy, diverging from orthodox Sunni Islam much more than other Muslim orders. For orthodox Islam, for instance, Muhammad and Ali are human beings and they cannot be of divine essence, much the same as for the doctrine of Trinity in Catholic orthodoxy there cannot be any hierarchical projection within a divine essence. Therefore, as Christian heresy pursue a doctrine of Docetism that refuses Trinity and denies the fusion of the divine and of human nature as inseparably united and fully achieved in the person of Christ, the divine identity of Muhammad and Ali, quite common to Bektashis, is a very extremist and heretic Shiite concept. However, Francis Trix's master Baba Rexheb, in one of his treatises on Bektashism, makes a clear distinction between them. Furthermore, he maintained that the order respects the rituals of faith and insisted that Bektashi rituals are not in opposition to Sunni Islam, that Bektashism is "within Islam" and, 
sometimes, that it is even the "real Islam". Allegations of this kind, fervently claimed by religious scholars or naïvely justified by seemingly well-intentioned local scholars, may well be noticed by specialists (e.g. Clayer 1990: 77-78; Norris 1993: 94), but without necessarily explaining - nor indeed understanding at all — that a deep evolution had been already achieved, not only in organizational and political structures, but also in theological and religious conceptions.

Basically, the rigid, intolerant and authoritarian attitudes of the local religious dignitaries, be they Muslim ulemas or Orthodox priests, as well as the formalism and dogmatism prevailing in all religious or political fields, simply express the haunting fear that they will lose their power. A religious leader might react first against established authority out of personal or factional interest or ambition, or he might be a channel for the expression of social discontents. Yet very soon leaders of heterodox movements will often aspire to political power, and are sometimes actually successful in founding a dynasty, as in the case of some mystical orders of Islam. Normally, religious leaders from local hagiocracies evolved into pillars of society and the established order. In fact, apart from the dangers of religious leaders revolting against established authority, which could only be successful under special conditions, there is always the possibility of their direct intervention in affairs of state. Consequently, the political authorities, well aware of their potentialities rooted as they are in the lives of the masses, often seek to control, regulate and conciliate rather than suppress them. Even the Albanian communist regime, like the Ottoman government in the past, was able to deal with almost all religious groups by playing off the more influential against each other.

Actually, the regime sought the support of instituted Bektashism as that of other religious denominations, and even took the initiative of imposing and controlling their doctrinal orthodoxy and hierarchical organization. All sorts of intimidation were used to this end, and it is certainly not a mere coincidence that every time that a new regime came to power, the highest level of Bektashi hierarchy suffered internal cabinet reshuffles, even leading to repeatedly mysterious murders. ${ }^{3}$ Certainly, with the power of communist ideology increasing, all religions, eliminated in 1967, were rendered purely and simply unnecessary. These trials and tribulations, in turn, created new conditions for Albanian Bektashism to once again become the religion of victims of persecution, as it did while sheltered in Cairo or in Michigan where Frances Trix found her master, before re-emerging in Albania after the downfall of communism in the 1990s.

\section{CONCLUSION}

The constant tension that subsists between orthodoxy and mystical movements is not exclusive to Islam. The transition from innovation to conservatism in theological conceptions and organizational structures, and the subsequent renewal of innovation in support of either liberating social and national movements or in the re-establishment of a new political power in human society, takes on different forms and tones, forming a complex process requiring detailed historical and anthropological analysis of the cultural values and social entities involved.

As a rule, historians and sociologists agree that there is a link between social and cultural frustration and religious movements, even though devotion to a religious heterodoxy can no longer be automatically be correlated with social protest. Religious movements have constituted preferred subjects of study for sociology. Be they the dissident, subversive, revolutionary or simply new or religious movements of a minority, they have often been labelled "sects". It was Max Weber (1988[1920]: 207-236) who first gave a sociological 
content to the antithetic terms of "Church" and "Sect", the former being opposed to the latter as an institution is opposed to a group bound by contractual, personal commitment. Weber considered mysticism to be a third element of the sociological conceptualization of religion besides the Church and the Sect, even though mysticism can be better regarded as an integral characterizing feature of the sect rather than a third term on its own.

The dominant trend in sociological tradition has conceptualized sects essentially as a form of religion structurally opposed to the overall society, including the State and the established Churches, at least inasmuch as they seem to be the pillars of society. While sects are viewed as potentially breaking with the societal order, sociologists admit that such rejection of the world may take on an enormous variety of forms and intensities. These may range from internalized forms of pietistic sects to open conflict, in the case of apocalyptic or revolutionary sects claiming to be the instrument of the complete overturning of the world (Desroche 1968). This is particularly true since the same organizations may adopt different attitudes at various points in their historical development. Consequently, the sociological notion of an irrevocable antagonism between sect and society must be relativized. At any point in time, a given sect may deny some aspects of the world and assert the value of some others.

Sociologically speaking, there is a first aspect, relatively unchanged throughout history, that is the opposition between conventional forms of religious life and innovative forms. Inasmuch as any religious movement is new, it possesses structural features that may generate conflict with the prevailing social order. The very fact that it claims to offer more rapid, more immediate, more concrete, in short different, access to salvation creates a tension with the conventional forms of religious experience within a given society. On the other hand, as a movement grows older, its more effusive manifestations tend to moderate, its values and norms are aligned on those of the surrounding world, and the meaning of religious, social and political opposition is attenuated. To persist, it is also obliged to accept some compromises with the outside world, at the risk of allowing its millenarian and mystical, sectarian and heterodox character to be diluted. However, the unbending law governing types of organization make it possible that sects become more like the rest of society, tending to be replaced by a new upsurge of spirited enthusiasm and intransigence.

Every church, having been a sect itself at its beginnings (i.e., a movement of social and religious protest breaking with society at large), ends up being reconciled with society. The first stage of this process normally occurs at the second generation of members. Characteristically, there is a loss of the original spontaneity in all fields, the creation of professional ministries, the adoption of oaths, a positive attitude toward society at large and the acceptance of pluralism. This transformation parallels the access of members of the group to respectable social status, and sects, originally very much in reaction against society at large, soon become established when the second generation takes the reins, even though there will always be a first generation to be recruited in a sect (Wilson 1990). Protest may come from inside a recognized religious group and establish an ecclesiola in Ecclesia, a religious order, collegium pietatis, characterized by mysticism as in the case of Bektashism. Yet it may also lead to dissidence, in which case we often observe the formation of ecclesiastic bodies of the church type, or of semi-ecclesiastic bodies such as autonomic churches or, again, of new sects to which ecclesiastic and theological terminology will preferably refer as either schism or heresy, and recent political discourse as fundamentalism.

The polemic against sects and heterodox religious movements is primarily and essentially expressed in terms of conflict on doctrinal grounds. On the other hand, while the sociological perspective has pointed to the economic and social roots of religious 
movements, it has tended to underestimate the importance of the religious structure itself. Up to now, the ideological and doctrinal field has been left exclusively in the hands of theologians, occasionally disputed by historians and religious scholars. I have discussed elsewhere the particular affinity that sociologists and anthropologists have always shown between new religious movements and social, cultural and national crisis movements (Doja 2000b: 677-679). The analysis of doctrinal-ideological and structural-organizational characteristics of Bektashism throughout its history, especially in Ottoman Anatolia and early independent Albania, that I have presented here is an illustrating suggestion that it is precisely on these grounds that a dialectical correlation may be addressed correctly. This can arguably be achieved if we begin by attempting to comprehend the underlying significance of the structure of religious representation and mediation. The point is not only that religion as a cultural symbolic system uses economic resources and has a power base, but, more importantly, as Bourdieu (1971) put it, religion, in its own field, has a symbolic structure that reproduces the distribution of resources and power from the nonsymbolic mundane field in a transformed form.

\section{Acknowledgements}

Part of the issues covered in this article were presented in a session on the ambiguous religious actors of Southeast Europe at the 7th Conference of the European Association of Social Anthropologists, Copenhagen, 14-17 August 2002. The general framework of the argument has been partly developed in a series of postgraduate lectures on the social construction of identities delivered during the 2000-2001 academic year at the University of Hull, and in ongoing postgraduate lecture series on historical anthropology delivered at the University of Limerick.

\section{Notes}

1. It might be ironic for the Serbian nationalist mythology that Milosh Kopilic, the grand hero who challenged and killed the Ottoman Sultan in the Battle was, if not Albanian, certainly not a Serb, according to the most realistic scholarship reviewed in Malcolm (1998: 58-80). Yet this puzzle should inform local scholars more about the transformational quality of mythical thought than about historical facts used for nationalist ideologies.

2. Deposited in the National Library of Naples, Italy, Kitabu irsadul muridin (The Book of Initiation) and Tarikatname (Brotherhood's Statutes) have been translated into Italian recently and analyzed for a Laurea thesis in historical-religious studies (Guidetti 1998).

3. The Bektashis claim, for instance, that their head-grandfather was murdered in 1941 by the Italian fascist regime of occupation because he did not accept collaboration. Later, after the advent of communist power, the Bektashis believe the head-grandfather committed suicide after killing his two assistants because they allegedly might have accepted collaboration with the communist regime. More recently, in the time of post-communist transition, the head of the Orthodox Church was expelled with a deportation order while the head of the Islamic Association was murdered in what some believe was an assassination by the fundamentalist faction to gain control of the direction of Islam in Albania.

\section{References}

Ayoub, Mahmoud. (1978) Redemptive Suffering in Islam: A Study of the Devotional Aspects of Ashura in Twelver Shiism (Mouton, The Hague).

Bartl, Peter. (1968) Die albanischen Muslime zur Zeit der nationalen Unabhängigkeitsbewegung, 1978-1912 (Albanische Forschungen, 8) (Harrassowitz, Wiesbaden).

Beldiceanu-Steinherr, Irene. (1991) "Les Bektachis à la lumière des recencements ottomans (XVe-XVIe siècles)", Wiener Zeitschrift für die Kunde des Morgenlandes 81, 21-80. 
Bianchi, Ugo. (1983) Il dualismo religioso: saggio storico ed etnologico (Ateneo, Rome).

Birge, John K. (1937) The Bektashi Order of Dervishes (Luzac Hartford Seminary Press, London).

Bloch, Maurice. (1985) "From cognition to ideology". In: Fardon, Richard, ed, Power and Knowledge: Anthropological and Sociological Approaches. Scottish Academic Press, Edinburgh, pp. 21-48.

Bougarel, Xavier and Clayer, Nathalie. (eds) (2001) Le nouvel Islam balkanique: les musulmans acteurs du postcommunisme (1990-2000) (Maisonneuve \& Larose, Paris).

Bourdieu, Pierre. (1971) “Genèse et structure du champ religieux”Revue Française de Sociologie 12(3), 295-334 (English trans.: (1991) Comparative Social Research 13, 1-44).

Bumke, Peter J. (1979) "Kizilbash-Kurden in Dersim (Tunceli, Türkei): Marginalität und Häresie”, Anthropos: International Review of Anthropology and Linguistics 74(3-4), 530-548.

Clayer, Nathalie. (1990) L'Albanie, pays des derviches: les ordres mystiques musulmans en Albanie à l'époque postottomane, 1912-1967 (Balkanologische Veröffentlichungen, 17) (Harrassowitz, Wiesbaden).

Clayer, Nathalie. (1992) "Bektachisme et nationalisme albanais", Revue des Études Islamiques 60(1), 271-300.

Clayer, Nathalie. (1994) Mystiques, État et Société: les Halvetis dans l'aire balkanique de la fin du 15e siècle à nos jours (Islamic History and Civilization 9) (Brill, Leiden).

Corbin, Henry. (1971) L’homme de lumière dans le soufisme iranien (Éditions Présence, Paris) (English trans.: Random House, Boulder, CO/New York, 1978).

Corbin, Henry. (1982) Temps cyclique et gnose ismaélienne (Berg International, Paris) (English trans.: Kegan Paul, London, 1983).

Corbin, Henry. (1983) Face de Dieu, face de l'homme: herméneutique et soufisme (Flammarion, Paris).

DeJong, Frederick. (1989) "The iconography of Bektashism: A survey of themes and symbolism in clerical costume, liturgical objects and pictorial art”, Manuscripts of the Middle East 4, 7-29.

Desroche, Henri. (1968) Sociologies religieuses (Presses Universitaires de France, Paris).

Doja, Albert. (1998a) "Évolution et folklorisation des traditions culturelles", East European Quarterly 32(1), 95-126.

Doja, Albert. (1998b) "Inscription patronymique et mythologie de fondation: Éléments d'analyse pour une généalogie des noms de personne chez les Albanais", Anthropos: International Review of Anthropology and Linguistics 93(1-3), 155-172.

Doja, Albert. (1999a) "Ethnicité, construction nationale et nationalisme dans l'aire albanaise: Approche anthropologique du conflit et des relations interethniques", Ethnologia Balkanica: Journal for Southeast European Anthropology 3, 155-179.

Doja, Albert. (1999b) "Formation nationale et nationalisme dans l'aire de peuplement albanais", Balkanologie: Revue de l'Association Française d'Études sur les Balkans 3(2), 23-43.

Doja, Albert. (1999c) "Morphologie traditionnelle de la société albanaise", Social Anthropology: Journal of the European Association of Social Anthropologists 7(1), 37-55.

Doja, Albert. (2000a) "Entre invention et construction des traditions: l'héritage historique et culturel des Albanais", Nationalities Papers 28(3), 417-448.

Doja, Albert. (2000b) "Histoire et dialectique des idéologies et significations religieuses", European Legacy: Journal of the International Society for the Study of European Ideas 5(5), 663-686.

Doja, Albert. (2000c) "The politics of religion in the reconstruction of identities: The Albanian situation", Critique of Anthropology 20(4), 421-438.

Doja, Albert. (2004) "Cultural politics and spiritual making of anthropologists", Reviews in Anthropology 33(1) (forthcoming).

Duijzings, Ger. (2000) Religion and the Politics of Identity in Kosovo (Hurst, London).

Elsie, Robert. (1995) History of Albanian Literature (East European Monographs 379) (Columbia University Press, Boulder, CO/New York).

Evans-Pritchard, Edward E. (1949) The Sanusi of Cyrenaica (Clarendon Press, Oxford).

Filipovic, Milenko S. (1954) "The Bektashi in the District of Strumica (Macedonia)", Man 54, 10-13.

Foucault, Michel. (1980) Power/knowledge: Selected Interviews and Other writings, 1972-1977 (ed, Colin Gordon) (Pantheon Books, New York).

Geertz, Clifford. (1973) "Religion as a cultural system". In: The Interpretation of Cultures. Basic Books, New York, pp. 87-125.

Goffman, Erving. (1974) Frame Analysis: An Essay on the Organization of Experience (Harper \& Row, New York).

Gossiaux, Jean-François. (1995) "Le sens et le verbe: sur deux modes opposés d'instrumentalisation politique du folklore", L'Homme: Revue Française d'Anthropologie 35(135), 127-134.

Guidetti, Vittoria Luisa. (1998) "Elementi dualistici e gnostici della religione Bektashi in Albania fra il XVII e il XIX secolo". In: Sfameni Gasparro, Giulia, ed, Destino e salvezza: tra culti pagani e gnosi cristiana. Itinerari storico-religiosi sulle orme di Ugo Bianchi, Hierá, 2. L. Giordano, Consenza, pp. 239-264.

Halimi, Kadri. (2000) "Dervishët dhe tempujte e tyre në përgjithësi dhe në Kosovë" [Dervishes and their institutions in Kosovo]. In: Trajtime dhe studime etnologjike [Ethnological studies and analyses]. (Instituti Albanologjik i Prishtinës, Prishtina, Kosovo), pp. 69-142.

Hasluck, Frederick W. (1929) Christianity and Islam under the Sultans (ed, Margaret M.H. Hasluck) (Clarendon Press, Oxford) (Reprint: Octagon Books, New York, 1973).

Izeti, Metin. (2001) Tarikati Bektashian (Çabej, Tetova, Macedonia). 
Leach, Edmund R. (1972) "Melchisedech and the Emperor: Icons of Subversion and Orthodoxy", Proceedings of the Royal Anthropological Institute of Great Britain and Ireland, 5-14.

Malcolm, Noel. (1998) Kosovo: A Short History (Macmillan, London).

Mann, Stuart E. (1955) Albanian Literature: An Outline of Prose, Poetry and drama (Quaritch, London).

Mélikoff, Irène. (1998) Hadji Bektach, un mythe et ses avatars: genèse et évolution du soufisme populaire en Turquie (Islamic History and Civilization 20) (Brill, Leiden).

Morozzo della Rocca, Roberto. (1990) Nazione e religione in Albania (1920-1944) (Mulino, Bologna).

Norris, Harry T. (1993) Islam in the Balkans: Religion and Society between Europe and the Arab World (Hurst, London).

Popovic, Alexandre. (1986) L'islam balkanique: les musulmans du sud-est européen dans la période post-ottomane (Balkanologische Veröffentlichungen 11) (Harrassowitz, Wiesbaden).

Ramsaur, Ernest. (1942) "The Bektashi dervishes and the Young Turks", Moslim World 32, 7-14.

Rexhepagiqi, Jashar. (1999) Dervishët, rendet dhe teqetë në Kosovë, ne Sanxhak e në rajonet e tjera përreth, në të kaluarën dhe sot [Dervishes, Orders and their Institutions in Kosovo, Sandjak and around, in the past and today] (Dukagjini, Peja, Kosovo).

Ricoeur, Paul. (1981) Hermeneutics and the Human Sciences: Essays on Language, Action and Interpretation (ed, John B. Thompson) (Cambridge University Press, Cambridge).

Skendi, Stavro. (1967) The Albanian National Awakening, 1878-1912 (Princeton University Press, Princeton, NJ).

Trimingham, J. Spencer. (1971) The Sufi Orders in Islam (Clarendon Press, Oxford).

Trix, Frances. (1993) Spiritual Discourse: Learning with an Islamic Master (Conduct and Communication Series) (University of Pennsylvania Press, Philadelphia, PA).

Weber, Max. (1978[1922]) Economy and Society: An Outline of Interpretive Sociology (eds, Guenther Roth and Claus Wittich) (University of California Press, Berkeley, CA).

Weber, Max. (1988[1920]) Gesammelte Aufsätze zur Religionssociologie, vol. 1 (ed, Marianne Weber) (Mohr, Tübingen).

Wilson, Bryan R. (1990) The Social Dimensions of Sectarianism: Sects and New Religious Movements in Contemporary Society (Clarendon Press/Oxford University Press, Oxford).

Xholi, Zija. (1998) Naim Frashëri midis së kaluarës dhe së sotmes [Naim Frashëri between Past and Present] (Luarasi, Tirana). 